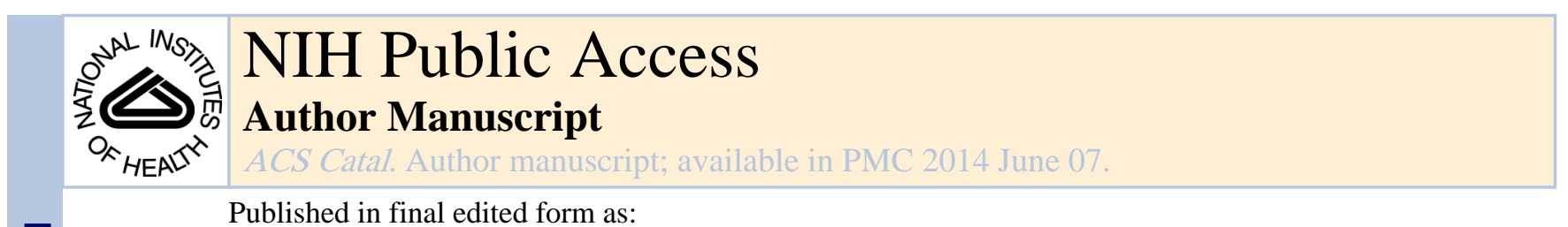

Published in final edited form as:

ACS Catal. 2013 June 7; 3(6): 1076-1091. doi:10.1021/cs4001249.

\title{
Catalytic Aminohalogenation of Alkenes and Alkynes
}

\author{
Sherry R. Chemler ${ }^{*}$ and Michael T. Bovino \\ Department of Chemistry, The State University of New York at Buffalo, Buffalo, New York, USA
}

Abstract

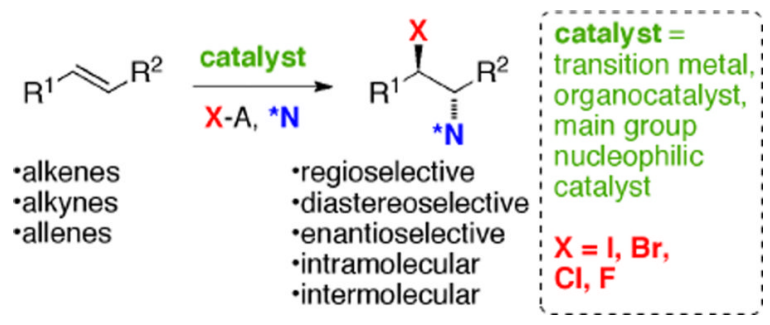

Catalytic aminohalogenation methods enable the regio- and stereoselective vicinal difunctionalization of alkynes, allenes and alkenes with amine and halogen moieties. A range of protocols and reaction mechanisms including organometallic, Lewis base, Lewis acid and Brønsted acid catalysis have been disclosed, enabling the regio- and stereoselective synthesis of halogen-functionalized acyclic amines and nitrogen heterocycles. Recent advances including aminofluorination and catalytic enantioselective aminohalogenation reactions are summarized in this review.

\section{Keywords}

aminohalogenation; catalysis; enantioselelective; alkenes; alkynes; allenes; haloamines; haloamidation

\section{INTRODUCTION}

Organic molecules containing both halogen and amine functional groups have been found in nature as bioactive secondary metabolites (Figure 1). ${ }^{1-5}$ Some vicinal amines of non-natural origin have also displayed significant bioactivity, for example, chlorambucil, a chemotherapeutic agent that acts by alkylating DNA (Figure 1).

Haloamines are also versatile intermediates in organic synthesis as the halogen can serve as a reactive functional group in substitution and cross-coupling reactions. Classical methods for the synthesis of haloamines usually involve activation of $\pi$-bonds with halonium ion sources (e.g. I $I_{2}$, NBS, NIS, NCS) followed by nucleophilic attack onto the halonium intermediate by an amine source. Such methods have demonstrated broad utility for the synthesis of fine chemicals, synthetic intermediates and natural products. Catalysis of the aminohalogenation reaction becomes important if the substrates do not produce the desired aminohalogen products by non-catalyzed methods or if reactivity, chemoselectivity,

*Corresponding Authors: Phone: 716-645-4225. schemler@buffalo.edu.

Author Contributions

The manuscript was written through contributions of all authors. All authors have given approval to the final version of the manuscript. 
regioselectivity and/or stereoselectivity can be specially imbued by the catalyst structure and mechanistic course it imparts to the reaction. We summarize herein recent developments in the catalytic aminohalogenation of alkenes and alkynes. The topic of alkene and alkyne aminohalogenation has been previously reviewed, ${ }^{6}$ so our review will focus on the developments reported in the last decade with particular attention given to the recent breakthroughs in aminofluorination and asymmetric catalysis.

\section{CATALYTIC AMINOHALOGENATION FOR THE SYNTHESIS OF ALKENES BEARING HALOGENS AND AMINES}

\subsection{Transition metal catalyzed intramolecular alkyne and allene aminohalogenation}

Bach and co-workers disclosed the room temperature Fe(II)-catalyzed synthesis of (Z)chlorooxazolidinones from propargyloxycarbonyl azides in the presence of TMSCl (1.5 equiv) in 2000 (Scheme 1). The reaction was catalyzed by $\mathrm{FeCl}_{2}(5-10 \mathrm{~mol} \%)$ and occurred with high Z-selectivity. Alkynes substituted with phenyl and $n$-butyl groups cyclized efficiently to give (Z)-chlorooxazolidines while $t$-butyl substituted alkynes provided nonhalogenated cyclization products (not shown).

The authors proposed Fe(II) reduction of the azide to an Fe(III)-coordinated nitrogen radical followed by cyclization onto the alkyne and intramolecular chlorine atom abstraction to produce the observed product stereoselectively (Scheme 2).

$\mathrm{Xu}$ and co-workers reported the synthesis of fluorinated pyrazoles via gold-catalyzed intramolecular alkyne aminofluorination using Selectfluor ${ }^{\circledR}$ as the halogen source in $2011 .^{7}$ A variety of fluorinated pyrazoles were synthesized in moderate to good yield at room temperature (Scheme 3). The efficiency of the reaction was somewhat diminished by formation of a competing hydroamination product. The authors established that the presence of the Au catalyst was required for the reaction to occur.

The authors proposed a mechanism involving an $\mathrm{Au}(\mathrm{I}) / \mathrm{Au}(\mathrm{III})$ catalytic cycle (Scheme 4).

$\mathrm{Xu}$ and Liu and demonstrated the Ag-catalyzed intramolecular aminofluorination of allenes and alkynes in 2011 and 2012, respectively. ${ }^{8,9}$ The endo-cyclization of 2-substituted 2allenyl sulfonamamides catalyzed by $\mathrm{AgNO}_{3}$ in the presence of $\mathrm{N}$ fluorobenzenesulfonimide (NFSI, 1.5 equiv) produced a range of 3-fluoro-3,4-unsaturated pyrrolidines in moderate to excellent yield (Scheme 5). ${ }^{8}$ It should also be noted that Pdcatalyzed exo-cyclization/aminohalogenation of allenes have previously been reported by Backvall and co-workers. ${ }^{10}$

A mechanism involving a $\mathrm{Ag}(\mathrm{I}) / \mathrm{Ag}(\mathrm{II})$ catalytic cycle was proposed for the endo cyclization (Scheme 6).

The Ag-catalyzed synthesis of 4-fluoroisoquinolines from the endo cyclization of alkynylimines was accomplished using similar reaction conditions (Scheme 7). ${ }^{9}$

\subsection{Copper-promoted aminohalogenation of indoles}

John and Nicholas disclosed an unusual copper-mediated double C-H functionalization of indoles and $\mathrm{N}$-methyl pyrrole for the synthesis of vicinally functionalized haloamines in 2012. ${ }^{11}$ Various oxime esters and $\mathrm{CuX}$ salts participate in the $\mathrm{C}-\mathrm{H}$ functionalization reaction to produce the respective haloamine adducts in moderate yield (Scheme 8). Yields were moderate due to formation of a competing indole mono-halogenation product, presumably formed from reaction of the indole with $\mathrm{CuX}_{2}$. 
The authors proposed a mechanism involving the active $\mathrm{Cu}\left(\mathrm{N}=\mathrm{CPh}_{2}\right) \mathrm{Br}(\mathrm{OAc})$ species which adds across the indole ring. Elimination of HOAc, insertion of halide into the $\mathrm{C}=[\mathrm{Cu}]$ bond and subsequent elimination of $\mathrm{Cu}-\mathrm{H}$ was then proposed to provide the haloamine product (Scheme 9).

\section{REGIOSELECTIVE AND DIASTEREOSELECTIVE CATALYTIC ALKENE AMINOHALOGENATION}

\subsection{Intramolecular Catalytic Aminohalogenation of Electron-rich Alkenes}

Gottlich and co-workers published a series of papers describing the catalytic cyclization/ aminochlorination of $N$-chloro- $N$-butenes between 2000-2004. ${ }^{12-16}$ The reactions can be catalyzed by $\mathrm{Cu}(\mathrm{I}),{ }^{12,13,15} \mathrm{HOAc}^{14}$ and $\mathrm{Bu}_{4} \mathrm{NI},{ }^{16}$ respectively. Electron-rich $\gamma$-unsaturated $\mathrm{N}$-chloroamines underwent diastereoselective cyclization to form chloropiperidines under catalysis by $\mathrm{CuCl}(10 \mathrm{~mol} \%)$ in $\mathrm{THF}$ at $50{ }^{\circ} \mathrm{C}$. Yields and diastereoselectivities were moderate to good (Scheme 10). ${ }^{12,15}$ The authors invoked a mechanism involving $\mathrm{N}-\mathrm{Cl}$ homolysis by $\mathrm{Cu}(\mathrm{I})$, generating a $\mathrm{Cu}(\mathrm{II})$-coordinated nitrogen radical. It is feasible this species could exist in equilibrium with a $\mathrm{Cu}(\mathrm{III})$-coordinated amine. Exo-selective addition of the nitrogen radical to the alkene, subsequent formation of an aziridinium ion with concomitant reduction of $\mathrm{Cu}(\mathrm{II})$ to $\mathrm{Cu}(\mathrm{I})$ and then regioselective opening of the aziridinium ion by chloride provides the chloropiperidine product (Scheme 10).

$\mathrm{N}$-Chloroamides and carbamates underwent $\mathrm{Cu}$-catalyzed cyclization with high exoselectivity and variable levels of diastereoselectivity (Scheme 11). ${ }^{13}$

Gottlich and co-workers subsequently found that $N$-chloropentamines can also undergo iodide-catalyzed ${ }^{16}$ and Lewis-acid promoted ${ }^{14}$ cyclizations, where more polar (non-radical) mechanisms are likely to be involved (Scheme 12).

In 2004, Chemler ${ }^{17}$ and $\mathrm{Lu}^{18}$ independently reported palladium-catalyzed intramolecular aminohalogenation/cyclization of $\gamma$ - and $\delta$-unsaturated sulfonamides where $\mathrm{CuBr}_{2}$ or $\mathrm{CuCl}_{2}$ served as both the stoichiometric oxidant and source of halide. Lu's study of the cyclization reactions of $N$-tosylcarbamates and ureas indicated that these substrates can undergo highly regio- and diastereoselective aminohalogenations (Scheme 13). ${ }^{18}$

Under similar conditions but without added LiX, Chemler and co-workers observed high regioselectivity in the aminohalogenation of an unsaturated tosylamide (Scheme 14) but obtained a mixture of regioisomers from $\mathrm{N}$-tosylpentene and $\mathrm{N}$-tosyl-2-allylanilines (Scheme 14). ${ }^{17}$ Formation of the exo regioisomers can be explained by exo-selective aminopalladation and subsequent oxidation and halide transfer, mediated by $\mathrm{CuBr}_{2}$. The formation of piperidine products may be explained by either endo-selective aminopalladation and subsequent oxidative halogenation or initial exo-selective aminopalladation followed by [Pd] displacement and aziridinium ion formation and subsquent nucleophilic attack by halide. The authors demonstrated that aminohalogenation products are not formed without added $\mathrm{CuBr}_{2}$ (e.g. stoichiometric $\mathrm{PdBr}_{2}$ does not give aminohalogenation products). They also demonstrated that $\mathrm{CuBr}_{2}$ in $\mathrm{CH}_{3} \mathrm{CN}$ (but not THF) at $23{ }^{\circ} \mathrm{C}$ can give a mixture of exo-selective aminobromination and alkene vicinal dibromination, possibly due to formation of $\mathrm{Br}_{2}$ under those conditions.

An exo-selective intramolecular aminochlorination of unsaturated amides and carbamates catalyzed by $\mathrm{PdCl}_{2}\left(\mathrm{CH}_{3} \mathrm{CN}\right)_{2}$ in the presence of $\mathrm{N}$-chlorosuccinimide as oxidant and halogen source was reported by Michael and co-workers in 2008 (Scheme 15). ${ }^{19}$ The authors propose a mechanism involving exo-selective aminopalladation followed by chlorination of the resulting organopalladium intermediate with NCS. ${ }^{19}$ 
Liu and co-workers reported an endo-selective Pd-catalyzed intramolecular cyclization/ aminofluorination of $\gamma$-pentenylsulfonamides for the synthesis of piperidines in 2009 (Scheme 16). ${ }^{20}$ The reaction occurs at room temperature in the presence of $\mathrm{PhI}(\mathrm{OCO} t \mathrm{Bu})_{2}$ ( 2 equiv) and $\mathrm{AgF}$ (5 equiv) and is thought to involve a $\mathrm{Pd}(\mathrm{II}) / \mathrm{Pd}(\mathrm{IV})$ catalytic cycle. An isotopically labeled substrate gave a 72:28 ratio of diastereomeric products (Scheme 16). The authors proposed that following trans-aminopalladation and oxidation to $\mathrm{Pd}(\mathrm{IV})$, either reductive elimination (favored) or $\mathrm{S}_{\mathrm{N}} 2$ displacement can occur to generate the C-F bond.

Liu and co-workers also reported an endo-selective Pd-catalyzed aminofluorination for the synthesis of fluoro-substituted pyrrolidines from $\beta$-alkenyl styrenes in $2011 .{ }^{21} \mathrm{~N}$ Fluorobenzenesulfonimide ( 3 equiv) was the fluorine source and oxidant. The substrate scope was limited to styrenes and the cis/trans diastereoselectivity was poor (Scheme 17). Diastereoselective was not affected by the geometry of the starting alkene. The authors proposed a catalytic cycle involving $\mathrm{Pd}(0) / \mathrm{Pd}(\mathrm{II})$ catalysis, which could explain the need for styrene substrates that can potentially form $\pi$-allyl type intermediates. The authors obtained a promising $44 \%$ ee using a chiral pincer-type ligand at $20^{\circ} \mathrm{C}$ (not shown).

Meng, Li and co-workers subsequently reported a metal-free endo-selective aminofluorination using $\mathrm{PhI}(\mathrm{OPiv})_{2}$ in the presence of $\mathrm{BF}_{3} \cdot \mathrm{OEt}_{2}\left(\mathrm{Scheme}_{18)}{ }^{22}\right.$ The authors propose the reaction mechanism involves formation and reaction of iodonium intermediates (Scheme 18).

\subsection{Intermolecular Catalytic Aminohalogenation of Styrenes and Electron-rich Alkenes}

3.2.1 Aminohalogenations Favoring Markovnikov Addition-In 2003, Sudalai and co-workers disclosed that copper(I)-catalyzed aminobromination of styrenes and electronrich alkenes with $\mathrm{N}$-bromosuccinimide (NBS) and tosylamine occurs efficiently and with high regioselectivity, favoring Markovnikov addition products (Scheme 19). ${ }^{23} \mathrm{MnSO}_{4}$ and $\mathrm{V}_{2} \mathrm{O}_{5}$ could also be used to catalyze this reaction. In diastereoselective reactions, the anti aminobromide predominated (Scheme 19). The authors suggested that the most probable intermediate in these reactions is a bromonium ion.

In 2008, Fu and co-workers reported an $\mathrm{FeCl}_{2}$-catalyzed aminobromination of alkylsubstituted alkenes where both amides and sulfonamides participated as the amine component in the reaction (Scheme 20). ${ }^{24}$ Markovnikov regioselectivity was observed and a mechanism involving a bromonium ion intermediate was proposed.

A related $\mathrm{FeCl}_{3}$-catalyzed aminochlorination of arylmethylenecyclopropanes has been reported by $\mathrm{Li}$ and co-workers ( $\mathrm{Eq} 1)$ but in their proposed mechanism, an aziridinium ion is the activated intermediate. ${ }^{25}$

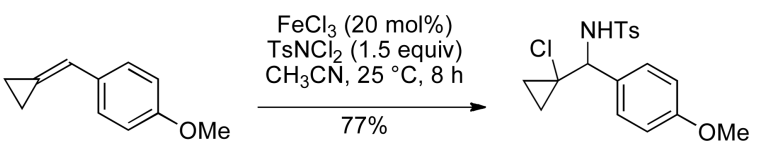

Liu and co-workers disclosed a regioselective Pd- catalyzed intermolecular aminofluorination of styrenes in 2010 using NFSI as the fluorine source and stoichiometric (2.5 equiv) oxidant (Scheme 21). ${ }^{26}$ The regioselectivity is analogous to a Markovnikov electrophile-initiated haloamination. The authors proposed a mechanism involving fluoropalladation and subsequent $\mathrm{C}-\mathrm{N}$ bond formation from the organopalladium 
intermediate. The authors propose both $\mathrm{Pd}(0) / \mathrm{Pd}(\mathrm{II})$ and $\mathrm{Pd}(\mathrm{II}) / \mathrm{Pd}(\mathrm{IV})$ pathways as mechanistic possibilities for the reactions (Scheme 21).

3.2.2 Markovnikov-Selective Catalytic Ritter-Type Aminohalogenations-Corey and co-workers reported a Lewis acid catalyzed, anti-selecctive haloamidation of electronrich alkenes where acetonitrile served as the amine source and $\mathrm{N}$-bromoacetamide served as the bromine source in 2006 (Eqs. 2-5). ${ }^{27}$ The reactions were catalyzed by $40 \mathrm{~mol} \% \mathrm{SnCl}_{4}$ (or 1 equiv of $\left.\mathrm{BF}_{3} \cdot \mathrm{OEt}_{2}\right)$ and took place at $0{ }^{\circ} \mathrm{C}\left(\right.$ or $\left.-40{ }^{\circ} \mathrm{C}\right)$ in $\mathrm{CH}_{3} \mathrm{CN}$ with trace $(1.2$ equiv) $\mathrm{H}_{2} \mathrm{O}$ present. This reaction was used in Corey's concise synthesis of Tamiflu (Eq 4). ${ }^{28}$ Markovnikov regioselectivity was observed (Eq 5), consistent with attack of a bromonium ion intermediate by acetonitrile.
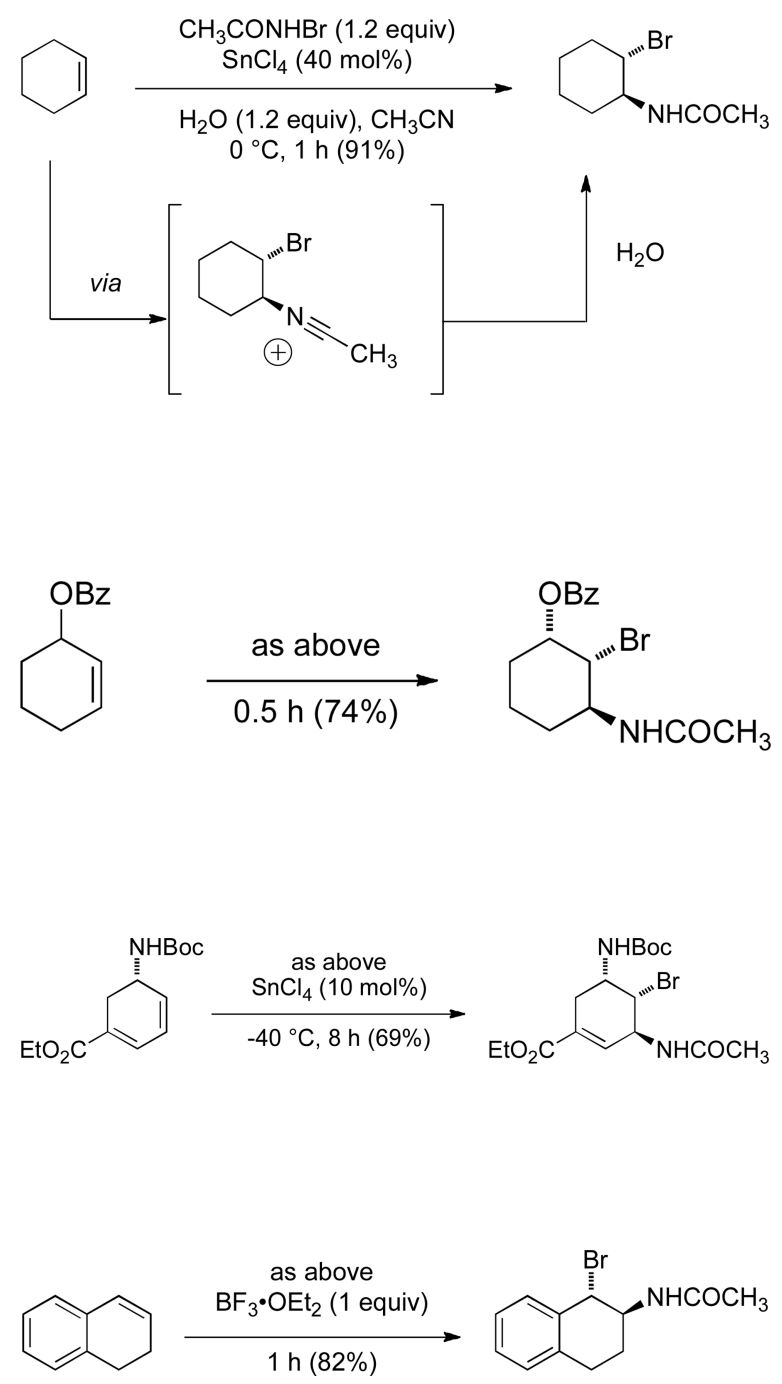

A mechanistically similar indium (III)-catalyzed Markovnikov-selective aminobromination and aminofluorination of styrenes was reported by Yadav and co-workers in 2009 (Eq 6). ${ }^{29}$ 

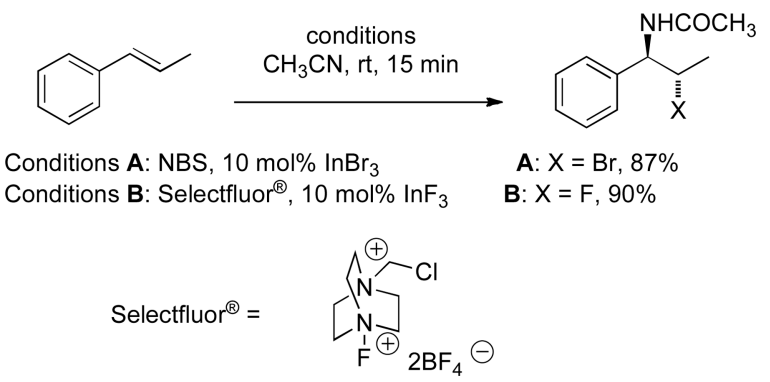

Yeung and co-workers subsequently reported a Lewis-base catalyzed chloroamidation of electron-rich alkenes using NCS as the chlorine source, acetonitrile as the amine source and diphenyl selenide as the Lewis basic catalyst (Scheme 22). ${ }^{30}$ Markovnikov selectivity was observed and the authors proposed $\left[\mathrm{Ph}_{2} \mathrm{SeCl}\right]^{+}$, formed in situ, to be the alkene chlorinating agent.

3.2.3 Styrene Aminohalogenations Favoring Anti-Markovnikov Addition-In their 2003 study, Sudalai and co-workers noted that in the presence of a Mn(III) catalyst, NBS and $\mathrm{TsNH}_{2}$ effect formation of anti-Markovnikov aminobromide products (Scheme 23). ${ }^{23}$ Similarly, the authors showed in a subsequent report that titanium superoxide was also capable of providing the anti-Markovnikov product selectively (Scheme 23). ${ }^{31}$ The authors believe the titanium superoxide catalyzed reaction goes through a mechanism involving catalyst activation of in situ-formed $\mathrm{TsNHBr}$ to provide a nitrogen radical which selectively adds to the styrene to produce the more stable benzylic radical, which then undergoes bromination (via atom abstraction or bromine radical quench).

$\mathrm{Li}$ and co-workers subsequently reported a catalyst-free anti-Markovnikov aminobromination of styrenes and alkyl-substituted alkenes using similar conditions and substrates but at $45^{\circ} \mathrm{C}$ and with $p$-TsNHMe as the nucleophile. ${ }^{32}$ The use of $p$-TsNHMe instead of $p$-TsNH2 was critical to the efficiency of their aminobromination.

\subsection{Intermolecular Catalytic Aminohalogenation of Electron-Deficient Alkenes}

$\mathrm{Li}$ and others have reported a number of regioselective and diastereoselective transitionmetal catalyzed aminohalogenations of $\alpha, \beta$-unsaturated esters, imides, ketones and nitriles. ${ }^{6,33-39}$ The copper(I)-catalyzed aminohalogenation of $\beta$-aryl-a, $\beta$-unsaturated esters ${ }^{37}$ and ketones ${ }^{35}$ generally provides anti-substituted $\alpha$-amino- $\beta$-halo-esters and ketones (Scheme 24). An aziridinium ion was invoked as the reaction intermediate; halide attack adjacent to the benzylic position rationalizes the observed regiochemistry. ${ }^{40,41}$ Substrates without $\beta$-aryl substitution favor formation of the $a$-halo- $\beta$-amino products (not shown). ${ }^{35}$

$\mathrm{Li}$ and co-workers subsequently disclosed both acid and base-catalyzed aminohalogenations of $\beta$-nitrostyrenes that provide $\alpha$-halo- $\beta$-amino and $a, \alpha$-dihalo- $\beta$-amino adducts, respectively (Scheme 25$).{ }^{42-50}$ For the former, a mechanism involving addition of a sulfonamide to a halonium ion intermediate was proposed. ${ }^{45}$ For the latter, a mechanism involving initial Michael addition into the nitroalkene followed by two sequential electrophilic halogenations was invoked to rationalize the regioselectivity. ${ }^{44}$ 


\section{CATALYTIC ENANTIOSELECTIVE ALKENE AMINOHALOGENATIONS}

In recent years, significant progress toward the catalytic enantioselective aminohalogenation of alkenes has been made. While the majority of the methods involve the intermediacy of electrophilic chiral halonium ions, ${ }^{51}$ alternative methods involving chiral nucleophilic intermediates $^{52}$ and halogen-atom transfer to chiral $\beta$-amino-radical intermediates ${ }^{53}$ have also been reported. As the utility of chiral vicinal aminohalides is likely to be high, it is expected the number of contributions in this area will continue to grow.

\subsection{Intramolecular Enantioselective Transition-Metal Catalyzed Alkene Aminohalogenation of Terminal Alkenes}

Bovino and Chemler reported a copper-catalyzed enantioselective intramolecular alkene aminohalogenation for the synthesis of chiral indolines and pyrrolidines in 2012 (Schemes 26 and 27). ${ }^{53}$ The reaction is catalyzed by $[\mathrm{Cu}(R, R)-\mathrm{Ph}$-box $](\mathrm{OTf})_{2}(20 \mathrm{~mol} \%)$ and isopropyl iodide is the source of halogen atom.

A range of substituents were tolerated and very good yields and enantioselectivities were obtained for several substrates. Substitution ortho to the sulfonamide, however, gave poor enantioselectivity (not shown) in the indoline series. The pyrrolidine-forming reactions (Scheme 27$)$ were best catalyzed by $[\mathrm{Cu}(4 R, 5 S)$-di-Ph-box $](\mathrm{OTf})_{2}$ which is more soluble and hence can improve catalytic reactivity (over background) when required. The synthesis of a six-membered ring via this route, however, resulted in low enantioselectivity (not shown).

The reaction is thought to involve a mechanism wherein chiral bis(oxazoline) ligands complexed with $\mathrm{Cu}(\mathrm{OTf})_{2}$ react with $\gamma$-alkenylsulfonamides via a stereodetermining cisaminocupration (Scheme 28). Subsequent C-[Cu(II)] homolysis and atom transfer from isopropyliodide provides the chiral heterocycle. $\mathrm{MnO}_{2}$ (see above) is the stoichiometric oxidant used to reoxidize $[\mathrm{Cu}(\mathrm{I})]$ to $[\mathrm{Cu}(\mathrm{II})]$. The isopropyl radical generated in the cycle is likely oxidized to propene under the reaction conditions.

\subsection{Intramolecular Enantioselective Organocatalytic Aminohalogenation of Unactivated Alkenes}

Shi and co-workers disclosed a method for the enantioselective cyclization/ aminohalogenation of alkenes catalyzed by a chiral phosphoric acid. ${ }^{54}$ The reaction scope is limited to internal $\gamma$-amino and $\gamma$-hydroxy alkenes, with cis, trans and tri-substituted alkenes all being well tolerated (Scheme 29). This reaction is also highlighted by its mild reaction conditions, proceeding at $0{ }^{\circ} \mathrm{C}$ in dichloromethane. One drawback to this reaction of this aminohalogenation is the extended reaction time (3 days) required for good conversions. Yields in this reaction range from 36-90\% and enantioselectivities from 56-91\%. In the case of the trans-methyl substrate, a small amount of the 6-endo product is formed as well.

The authors proposed that the phosphoric acid acts as a bifunctional catalyst, having both acidic and basic sites, to activate both the electrophile (NBS) and the nucleophile (amine) through hydrogen bonding. Hydrogen bonding as well as $N$-protecting group steric interactions help to orient the substrate. For the cis-alkenes the $N$-protecting group is oriented away from the bulky aryl groups of the catalyst which in turn projects the alkyl chain under the NBS (in a psuedoendo fashion) forcing the nucleophile to attack from the bottom face of the olefin, Scheme 30 .

Yeung and co-workers reported an enantioselective bromoaminocyclization catalyzed by chiral amino-thiocarbamates for the synthesis of 2-(bromomethyl)-1-(4nitrophenylsulfonyl)pyrrolidines from 4-nitro- $N$-(pent-4-enyl)benzenesulfonamides, Scheme 
31. ${ }^{55}$ Generally, 1,1-disubstituted olefin substrates performed best in this reaction, especially those with aryl substitution. Alkyl substitution was generally tolerated, albeit with significantly reduced enantioselectivity ( $<50 \%$ ee). Yields for this transformation are generally excellent (61-99\%) and enantiomeric excesses range from 10-98\%. Reaction times are 3-6 days, which is a drawback. The aminohalogenation was run on a $2 \mathrm{mmol}$ scale with no loss in efficiency or selectivity.

The amino-thiocarbamate catalyst is believed to work as a bifunctional catalyst, activating both the nucleophile and the electrophile via hydrogen bonding or ion pairing. The catalyst also works to organize and orient all of the reaction participants through hydrogen bonding, steric interactions and potentially $\pi$-stacking of aromatic rings between the substrate and catalyst. The olefin conformation in the transition state is believed to be governed by the steric interactions between the olefin R-group and the 2,6-ethoxy groups on the aryl ring of the catalyst, Scheme 32 .

The pyrrolidine products were shown to be useful building blocks as the Ns group could be readily removed to yield the bicyclic aziridine in good yield or the pyrrolidine could be readily oxidized to the lactam also in good yield, both with no loss in enantioenrichment. Lastly, using the same catalyst as in Schemes 31 and 32, the group was also able to show that the reaction could be used to produce isoindolines, potentially valuable synthetic building blocks, and that these products could also be readily oxidized to their isoindolinone counterparts without loss of the bromine functionality or enantiomeric purity (Scheme 33).

The enantioselective 5-exo-dig aminobromination of trisubstituted alkenes catalyzed by a chiral selenide Lewis base has recently been reported for the synthesis of more substituted pyrrolidines using $N$-bromopthalimide (NBP) as the bromine source (e.g. Eq. 7). ${ }^{56}$

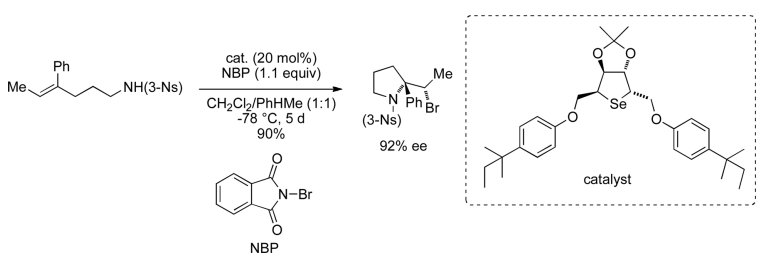

Jacobsen and co-workers recently demonstrated the 6-exo-trig cyclization/aminoiodination of alkenyl trichloroacetimidates catalyzed by a chiral Schiff-base urea derivative. ${ }^{57} 1,1$ Disubstituted vinylarenes underwent this reaction with the highest enantioselectivity (Scheme 34). The authors propose the catalyst acts as a neutral phase transfer catalyst (with urea NH's hydrogen bonding to an oxygen of NIS) since NIS has poor solubility in the reaction medium.

Yeung and co-workers have also disclosed the enantioselective synthesis of 2-substituted 3bromopyrrolidines via 5-endo-trig enantioselective aminobromination/cyclization of 4substituted $N$-(but-3-enyl)-4-nitrobenzenesulfonamides. ${ }^{58}$ Of those substrates tested, those bearing alkyl, heteroaryl, aryl and substituted aryl groups all participated in the reaction. Product yields were reported as moderate to excellent (56-98\%) with generally good enantioselectivities (47-91\% ee, Scheme 35).

Substrates bearing aryl groups with strongly electron donating substituents at the 4-position participated in the reaction but reacted with low enantoiselectivity ( $<50 \%$ ee, not shown). This phenomenon was attributed to the destabilizing affect these groups have on the 
proposed halonium intermediate. $N$-Bromothalimide (NBP) was used as the electrophilic bromine source, with a $10 \mathrm{~mol} \%$ catalyst loading at $-78^{\circ} \mathrm{C}$ in a $1: 1$ chloroform: $n$-hexane solvent system requiring reaction times of about 5 days. The catalyst is believed to work by organizing and activating the reactants. Only endo-cyclization is possible for the reaction with but-3-enyl substrates and products with the bromine atom directly on the pyrrolidine ring are produced, Figure 2.

The aminothiocarbamate-catalyzed 6-endo-trig cyclization of 5-aryl-bishomoallylic sulfonamides in the presence of 1,3-dibromo-5,5-didimethylhydantoin (DBH) was also found to enable the synthesis of chiral substituted piperidines (Eq. 8). ${ }^{59}$

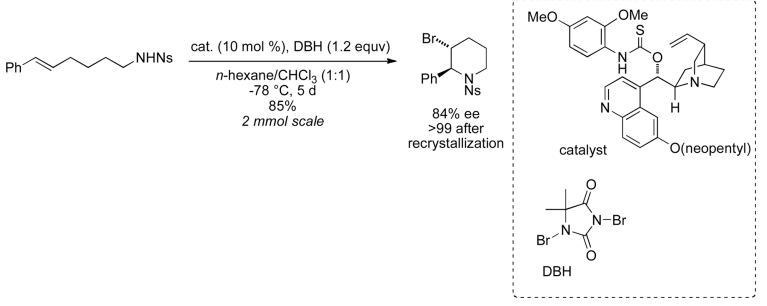

The first enantioselective intramolecular aminofluorination was reported by Gouverneur and co-workers in $2011 .{ }^{60}$ Various tryptamine derivatives underwent electrophilic fluorination/ cyclization using $N$-fluorobenzenesulfonamide (NFSI) in the presence of $20 \mathrm{~mol} \%$ of Sharpless's (DHQ) ${ }_{2}$ PHAL ligand (Scheme 36). Conditions using a stoichiometric amount of chiral ligand gave enantioselectivities up to $90 \%$ (not shown).

\subsection{Intermolecular Enantioselective Organocatalytic Aminohalogenation of Electron-Rich Alkenes}

Masson and co-workers disclosed the enantioselective a-bromination of enecarbamates, catalyzed by chiral phosphoric acids and calcium phosphate salts, in $2012 .{ }^{61}$ The reaction proceeds with low catalyst loadings, $1 \mathrm{~mol} \%$, in toluene at room temperature in about fourteen hours, providing very mild reaction conditions. Products were obtained in moderate to excellent yields (46-99\%) with generally excellent enantiomeric excess (81-98\% ee, Scheme 37).

Several modifications were made to the carbamate moiety of the substrate (including alkyl and unsaturated substituents) and were well tolerated as were a wide range of linear and branched alkyl (saturated and unsaturated) and heteroalkyl groups on the alkene. A $\beta, \beta$ disubstituted alkene participated in the reaction to give product with a fully substituted carbon with $96 \%$ ee (absolute configuration not determined), illustrating the robustness of the reaction. It was found that vinyl carbamates with aryl groups at the $\beta$-position did not participate in the reaction, a result the group ascribes to the lower nucleophilicity of such substrates. Also noteworthy, is that secondary enecarbamates were unreactive, further supporting the hypothesis that the catalyst activates both reagents. The catalyst is hypothesized to activate the NBS either by hydrogen bonding or ion pairing, increasing the electrophilic character of the halogen atom. At the same time, the substrate is similarly activated, in order to increase nucleophilicity and to organize reactants. Enamine attack on NBS installs the halogen atom and generates a chiral imine intermediate, which is subsequently attacked by the newly generated succinimide nucleophile (Scherme 38). Interestingly, the opposite enantiomer can be accessed via the use of the correspoinding calcium bis(phosphate) salt catalyst (not shown). 


\subsection{Intermolecular Enantioselective Organocatalytic Alkene Aminohalogenation of Electron-Deficient Alkenes}

In 2010 Brenner-Moyer and co-workers disclosed a novel organocatalytic cascade reaction for the enantioselective aminofluorination of olefins. ${ }^{52}$ This cascade sequence uses methyltert-butyl ether (MTBE) as a solvent and proceeds from room temperature to $0{ }^{\circ} \mathrm{C}$ with 20 mol\% catalyst loading. Reaction products were produced in modest to good yields (24-73\%) with excellent syn:anti diastereoselectivity (87:13 to 98:2) and enantioselectivity (80-99\% ee, Scheme 39). Several a, $\beta$-unsaturated aldehydes were found to participate in the reaction sequence including those with branched, linear and heteroalkyl substitution as well as aromatic and olefin $\mathrm{R}$ groups. Prolonged reaction times are a drawback to this reaction with most requiring several days.

This cascade involves two different reactions performed in tandem, catalyzed by the same prolinol-derived catalyst. The first reaction involves enantioselective conjugate addition of an amine to an $a, \beta$-unsaturated iminium intermediate. The $\mathrm{C}-\mathrm{F}$ bond is then made by electrophilic fluorination of a chiral enamine intermediate (Scheme 40). In both the nucleophilic, as well as the electrophilic additions the catalyst effectively blocks one face of the substrate leading to the observed stereochemistry. These reaction products can be readily converted into $a$-fluoro- $\beta$-amino acid derivatives in a couple steps with no appreciable loss in enantiomeric excess.

\subsection{Intermolecular Enantioselective Lewis-Acid Catalyzed Aminohalogenation of Electron- Deficient Alkenes}

Scandium(III) triflate complexed to chiral $N, N^{\prime}$-dioxide ligands can effect the intermolecular diastereo- and enantioselective aminochlorination, aminobromination and aminoiodination of variously substituted $a, \beta$-unsaturated ketoesters and chalcones in the presence of tosylamide and NBS, NIS, $\mathrm{TsNCl}_{2}$ or derivatives thereof. Feng and co-workers disclosed the enantioselective bromoamination of chalcones in 2010 using this catalyst (Table 1). ${ }^{62}$ The reaction was highly regio- and diastereoselective, favoring the trans-abromo- $\beta$-amino ketone. The enantioselectivity was also very high (ee's $>95 \%$ ). A diverse range of aryl and substituted aryl groups were examined with all giving both excellent yields and enantioselectivities. Except for a couple of examples all reactions also proceeded to give products with a $>99: 1$ diastereomer ratio.

Using the same ligand as in Table 1, rigid enones of the type depicted in Scheme 41 were also shown to be suitable substrates for this transformation giving products that contain a quaternary stereocenter.

The phenethyl R group on the amide nitrogen of the ligand was found to be the most optimal. Increasing or decreasing the length of the carbon chain between the nitrogen and phenyl all resulted in either lower yield or enantioselectivity, relative to the ethyl chain. A reduction in the size of the $\mathrm{N}$-oxide ring also resulted in decreased yield and selectivity. Use of molecular sieves dramatically impacted the reaction yield. The efficiency of this reaction was demonstrated on gram scale (using the substrate in Table 1, entry 1) and provided the aminobromide product in $96 \%$ yield, $96 \%$ ee and $>99: 1$ d.r. at 0.05 mol\% catalyst loading.

The reaction is believed to proceed through a chiral bromonium intermediate. The Lewis acid coordinates to the enone carbonyl as well as the bromine source allowing for a face selective formation of the bromonium ion that could then be rapidly intercepted by the nitrogen nucleophile. TsNHBr, generated in situ, is thought to be the most likely source of the bromine and amine nucleophile. This enables the catalyst to coordinate to the sulfonyl oxygen and direct the bromination, leaving the newly generated anion proximal for the attack (Scheme 42). ${ }^{63}$ 
The enantioselective chloroamination of $a, \beta$-unsaturated $\gamma$-keto esters and chalcones was reported in 2011 (Table 2). ${ }^{63}$ Chlorination via an electrophilic pathway tends to be more challenging due to the increased electronegativity and decreased atomic radius of chlorine relative to bromine. For this variation the ligand $\mathrm{R}$ group was changed to the very bulky adamantyl to give the desired products in high enantioselectivity. In this reaction the authors note that increasing the bulk of the ester substituent leads to a decrease in yield. Substrates with aromatic rings bearing electron-withdrawing groups gave products with slightly lower diastereoselectivities, assumed to be caused from the reduced stability of the proposed chloronium ion intermediate.

The enantioselective chloroamination of chalcones also occurred with high regio-, diastereoand enantioselectivity using the adamantyl-substituted ligand (Table 3). During the course of this investigation Feng and co-workers proposed that the $4 \AA$ mol sieves served to accelerate the formation of the proposed active species, TsNHCl, via reaction of NCS with $\mathrm{TsNH}_{2}$.

A catalytic enantioselective aminoiodination of chalcones was reported in $2011 .{ }^{64} \mathrm{By}$ keeping the reaction strictly anhydrous with the exclusion of light, Feng and co-workers were able to effect the desired transformation across a wide variety of chalcones with high yields and excellent enantio- and diastereoselectivity (Table 4). This reaction generally requires a $0.5 \mathrm{~mol} \%$ catalyst loading and $2.0 \mathrm{~mol} \%$ loading for more challenging substrates.

Several $\alpha, \beta$-unsaturated $\gamma$-keto esters also underwent the enantioselective iodoamination efficiently with the phenethyl-substituted ligand (Table 5). It was noted that extreme bulk on the ester group led to a decrease in yield.

The synthesis of a-halo- $\beta$-amino- $\beta$-trifluoromethyl enones was demonstrated with each $\mathrm{Sc}(\mathrm{III})$-catalyzed aminohalogenation method using the phenethyl-substituted ligand (Scheme 43).

\subsection{Summary and Outlook}

It is anticipated that vicinal haloamines will continue to find use in organic synthesis and medicinal chemistry. Considerable progress in catalytic aminohalogenation reaction technology has been made in the last decade, allowing for unprecedented chemo-, regio- and stereoselectivity. The diversity of reaction mechanisms and protocols for alkene and alkyne aminohalogenation significantly enables versatility in synthetic planning. Many of the reactions summarized in this review are tailored for a specific substrate class, so judicious choice of an aminohalogenation protocol among the complementary methods is necessary. Future progress in alkene aminohalogenation technology should involve optimization of reaction protocols for catalyst loading, substrate scope, atom economy, reaction times and enantioselectivity. Methods focusing on high chemoselectivity and enantioselectivity and more sustainable reaction protocols will inevitably prove the most useful to the chemical and pharmaceutical industry.

\section{Acknowledgments}

Aminohalogenation research in our group is supported by the National Institutes of Health (GM078383).

\section{REFERENCES}

1. Gribble, GW. Chapter 1 -- Occurence of Halogenated Alkaloids. Vol. 71. Academic Press; 2012.

2. Nakamura H, Ohizumi Y, Kobayashi J, Hirata Y. Tetrahedron Lett. 1984; 25:2475-2478.

3. Nakagawa A, Iwai Y, Hashimoto H, Miyazaki N, Oiwa R, Takahashi Y, Hirano A, Shibukawa N, Kojima Y, Omura S. J. Antibiot. 1981; 34:1408-1415. [PubMed: 7319904] 
4. Kinnel RB, Gehrken H-P, Scheuer PJ. J. Am. Chem. Soc. 1993; 115:3376-3377.

5. Qiu J, Silverman RB. J. Med. Chem. 2000; 43:706-720. [PubMed: 10691696]

6. Li G, Kotti SRSS, Timmons C. Eur. J. Org. Chem. 2007:2745-2758.

7. Qian J, Liu Y, Zhu J, Jiang B, Xu Z. Org. Lett. 2011; 13:4220-4223. [PubMed: 21774521]

8. Xu T, Mu X, Peng H, Liu G. Angew. Chem. Int. Ed. 2011; 50:8176-8179.

9. Xu T, Liu G. Org. Lett. 2012; 14:5416-5419. [PubMed: 23088282]

10. Jonasson C, Horvath A, Backvall J-E. J. Am. Chem. Soc. 2000; 122:9600-9609.

11. John A, Nicholas KM. Organometallics. 2012; 31:7914-7920.

12. Göttlich R. Synthesis. 2000:1561-1564.

13. Schulte-Wulwer IA, Helaja J, Göttlich R. Synthesis. 2003:1886-1890.

14. Noack M, Kalsow S, Göttlich R. Synlett. 2004:1110-1112.

15. Heuger G, Kalsow S, Göttlich R. Eur. J. Org. Chem. 2002:1848-1854.

16. Noack M, Göttlich R. Eur. J. Org. Chem. 2002:3171-3178.

17. Manzoni MR, Zabawa TP, Kasi D, Chemler SR. Organometallics. 2004; 23:5618-5621.

18. Lei A, Lu X, Liu G. Tetrahedron Lett. 2004; 45:1785-1788.

19. Michael FE, Sibbald PA, Cochran BM. Org. Lett. 2008; 10:793-796. [PubMed: 18247496]

20. Wu T, Yin G, Liu G. J. Am. Chem. Soc. 2009; 131:16354-16355. [PubMed: 19856929]

21. Xu T, Qiu S, Liu G. Chinese J. Chem. 2011; 29:2785-2790.

22. Wang Q, Zhong W, Wei X, Ning M, Meng X, Li Z. Org. Biomol. Chem. 2012; 10:8566-8569. [PubMed: 23007735]

23. Thakur VV, Talluri SK, Sudalai A. Org. Lett. 2003; 5:861-864. [PubMed: 12633091]

24. Wang Z, Zhang Y, Fu H, Jiang Y, Zhao Y. Synlett. 2008:2667-2670.

25. Li Q, Shi M, Timmons C, Li G. Org. Lett. 2006; 8:625-628. [PubMed: 16468727]

26. Qiu S, Xu T, Zhou J, Guo Y, Liu G. J. Am. Chem. Soc. 2010; 132:2856-2857. [PubMed: 20148557]

27. Yeung Y-Y, Gao X, Corey EJ. J. Am. Chem. Soc. 2006; 128:9644-9645. [PubMed: 16866514]

28. Yeung Y-Y, Hong S, Corey EJ. J. Am. Chem. Soc. 2006; 128:6310-6311. [PubMed: 16683783]

29. Yadav JS, Reddy BVS, Chary DN, Chandrakanth D. Tetrahedron Lett. 2009; 50:1136-1138.

30. Tay DW, Tsoi IT, Er JC, Leung GYC, Yeung Y-Y. Org. Lett. 2013; 15:1310-1313. [PubMed: 23461531]

31. Shaikh TM, Karabal PU, Suryavanshi G, Sudalai A. Tetrahedron Lett. 2009; 50:2815-2817.

32. Zhang G, An G, Zheng J, Pan Y, Li G. Tetrahedron Lett. 2010; 51:987-989.

33. Sun H, Zhi S-J, Han J-L, Li G, Pan Y. Chem. Biol. Drug Des. 2010; 75:269-276. [PubMed: 20331646]

34. Sun H, Zhang G, Zhi S, Han J, Li G, Pan Y. Org. Biomol. Chem. 2010; 8:4236-4239. [PubMed: 20714671]

35. Chen D, Timmons C, Chao S, Li G. Eur. J. Org. Chem. 2004; 2004:3097-3101.

36. Xu X, Kotti SRSS, Liu J, Cannon JF, Headley AD, Li G. Org. Lett. 2004; 6:4881-4884. [PubMed: 15606090]

37. Li G, Wei H-X, Kim SH. Org. Lett. 2000; 2:2249-2252. [PubMed: 10930255]

38. Wang Y-N, Kattuboina A, Ai T, Banerjee D, Li G. Tetrahedron Lett. 2007; 48:7894-7898.

39. Han J-L, Zhi S-J, Wang L-Y, Pan Y, Li G. Eur. J. Org. Chem. 2007:1332-1337.

40. Wei H-X, Kim SH, Li G. Tetrahedron. 2001; 57:3869-3873.

41. Li G, Wei H-X, Kim SH. Tetrahedron. 2001; 57:8407-8411.

42. Mei H, Han J, Li G, Pan Y. RSC Advances. 2011; 1:429-433.

43. Mei H, Xiong Y, Qian Y, Han J, Li G, Pan Y. RSC Advances. 2012; 2:151-155.

44. Ji X, Duan Z, Qian Y, Han J, Li G, Pan Y. RSC Advances. 2012; 2:5565-5570.

45. Zhi S-J, Sun H, Zhang G, Li G, Pan Y. Org. Biomol. Chem. 2010; 8:628-631. [PubMed: 20090980] 
46. Sun H, Han J, Kattamuri PV, Pan Y, Li G. J. Org. Chem. 2013; 78:1171-1175. [PubMed: 23311641]

47. Qian Y, Ji X, Zhou W, Han J, Li G, Pan Y. Tetrahedron. 2012; 68:6198-6203.

48. Zhi S, An G, Sun H, Han J, Li G, Pan Y. Tetrahedron Lett. 2010; 51:2745-2747.

49. Zhi S, Han J, Lin C, An G, Pan Y, Li G. Synthesis. 2008; 2008:1570-1574.

50. Ji X, Mei H, Qian Y, Han J, Li G, Pan Y. Synthesis. 2011; 2011:3680-3686.

51. Denmark SE, Kuester WE, Burk MT. Angew. Chem. Int. Ed. 2012; 51:10938-10953.

52. Appayee C, Brenner-Moyer SE. Org. Lett. 2010; 12:3356-3359. [PubMed: 20575576]

53. Bovino MT, Chemler SR. Angew. Chem. Int. Ed. 2012; 51:3923-3927.

54. Huang D, Wang H, Xue F, Guan H, Li L, Peng X, Shi Y. Org. Lett. 2011; 13:6350-6353. [PubMed: 22092000]

55. Zhou L, Chen J, Tan CK. J. Am. Chem. Soc. 2011; 133:9164-9167. [PubMed: 21539367]

56. Chen F, Tan CK, Yeung Y-Y. J. Am. Chem. Soc. 2013; 135:1232-1235. [PubMed: 23312005]

57. Brindle CS, Yeung CS, Jacobsen EN. Chem. Sci. 2013; 4:2100-2104.

58. Chen J, Zhou L, Yeung Y-Y. Org. Biomol. Chem. 2012; 10:3808-3811. [PubMed: 22437158]

59. Zhou L, Tay DW, Chen J, Leung GYC, Yeung Y-Y. Chem. Comm. 2013

60. Lozano O, Blessley G, Martinez del Campo T, Thompson AL, Giuffredi GT, Bettati M, Walker M, Borman R, Gouverneur V. Angew. Chem. Int. Ed. 2011; 50:8105-8109.

61. Alix, Al; Lalli, C.; Retailleau, P.; Masson, Gr. J. Am. Chem. Soc. 2012; 134:10389-10392. [PubMed: 22686436]

62. Cai Y, Liu X, Hui Y, Jiang J, Wang W, Chen W, Lin L, Feng X. Angew. Chem. Int. Ed. 2010; 49:6160-6164.

63. Cai Y, Liu X, Jiang J, Chen W, Lin L, Feng X. J. Am. Chem. Soc. 2011; 133:5636-5639. [PubMed: 21443187]

64. Cai Y, Liu X, Li J, Chen W, Wang W, Lin L, Feng X. Chem. - Eur. J. 2011; 17:14916-14921. [PubMed: 22161911] 
<smiles>Cn1c(/C=C\CCC(=O)c2cc(Br)c[nH]2)cnc1N</smiles>

keramadine serotonergic receptor antagonist<smiles>COC[C@@]1(CCC(C)=C(C)C)Nc2ccc(C(=O)O)cc2C[C@H]1Cl</smiles>

virantmycin antiviral antibiotic<smiles>N[C@@H]1C[C@H](C(=O)O)CC1F</smiles>

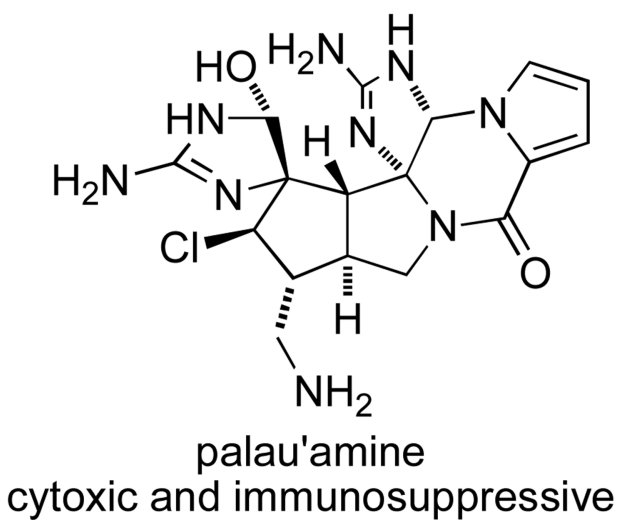<smiles>O=C(O)CCCc1ccc(N(CCCl)CCCl)cc1</smiles>

Figure 1.

Representative biologically active haloamines. 


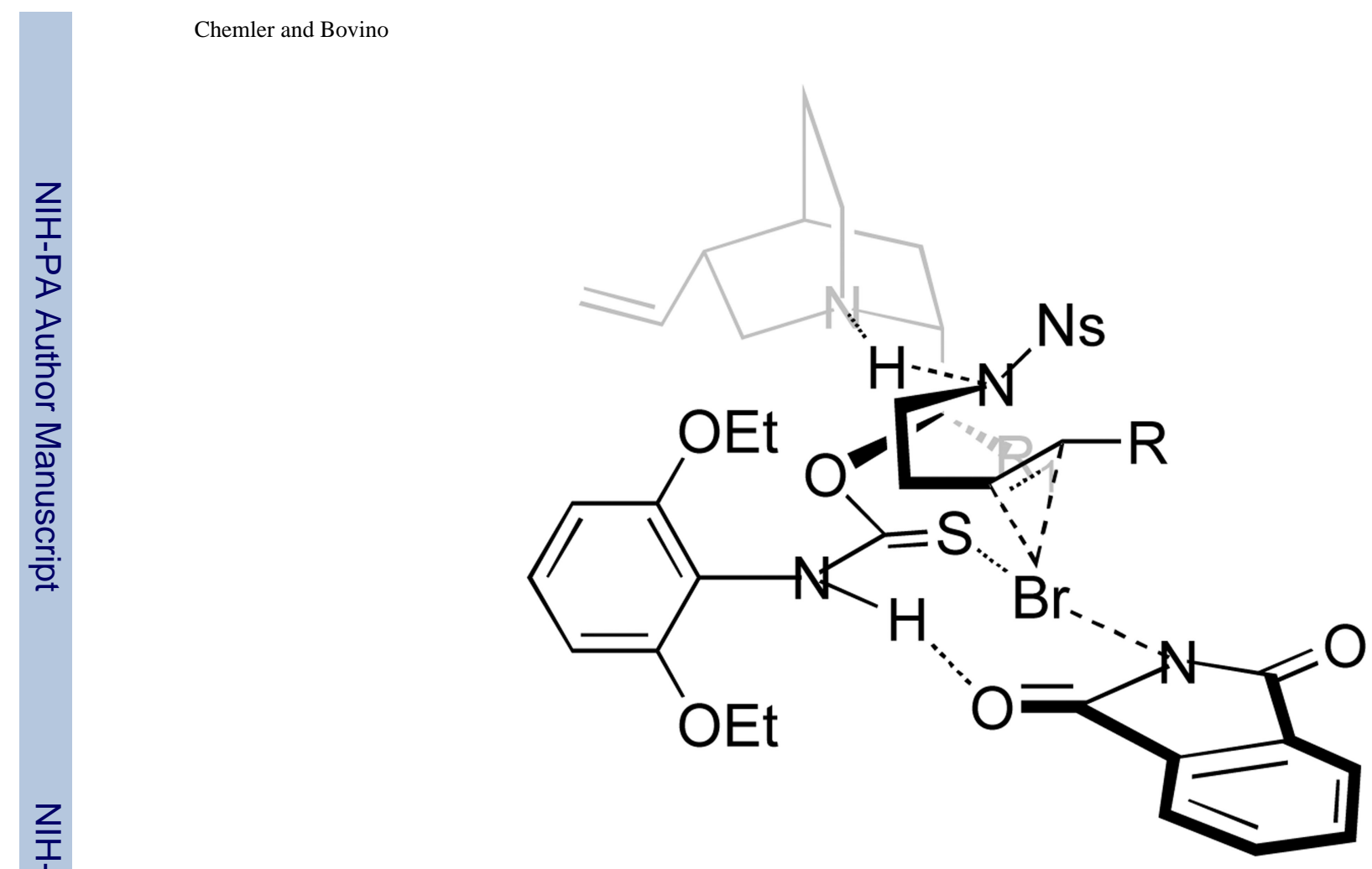

Figure 2.

Proposed Transition State for Amino-Thiocarbamate Catalysis 

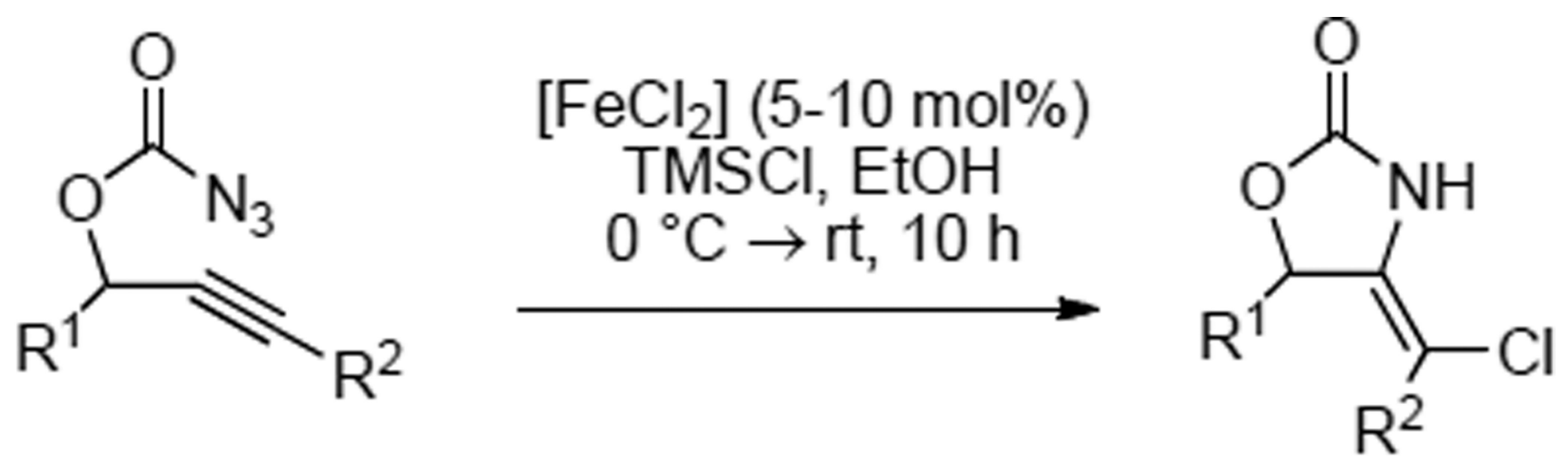

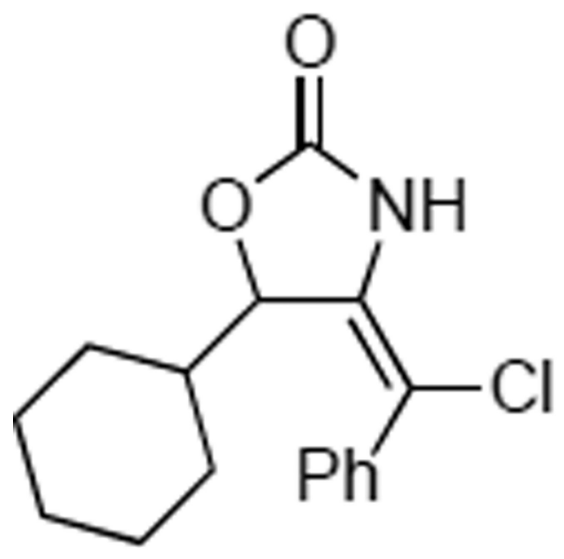

$98 \%$

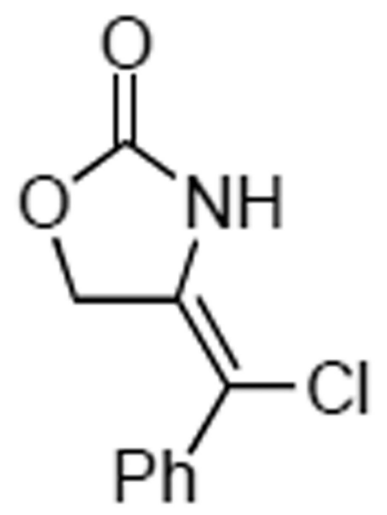

$99 \%$

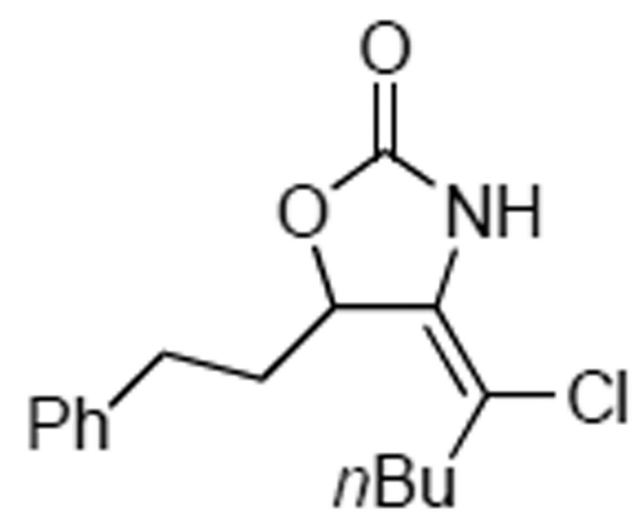

$81 \%$

Scheme 1.

Iron-Catalyzed Alkyne Aminochlorination 

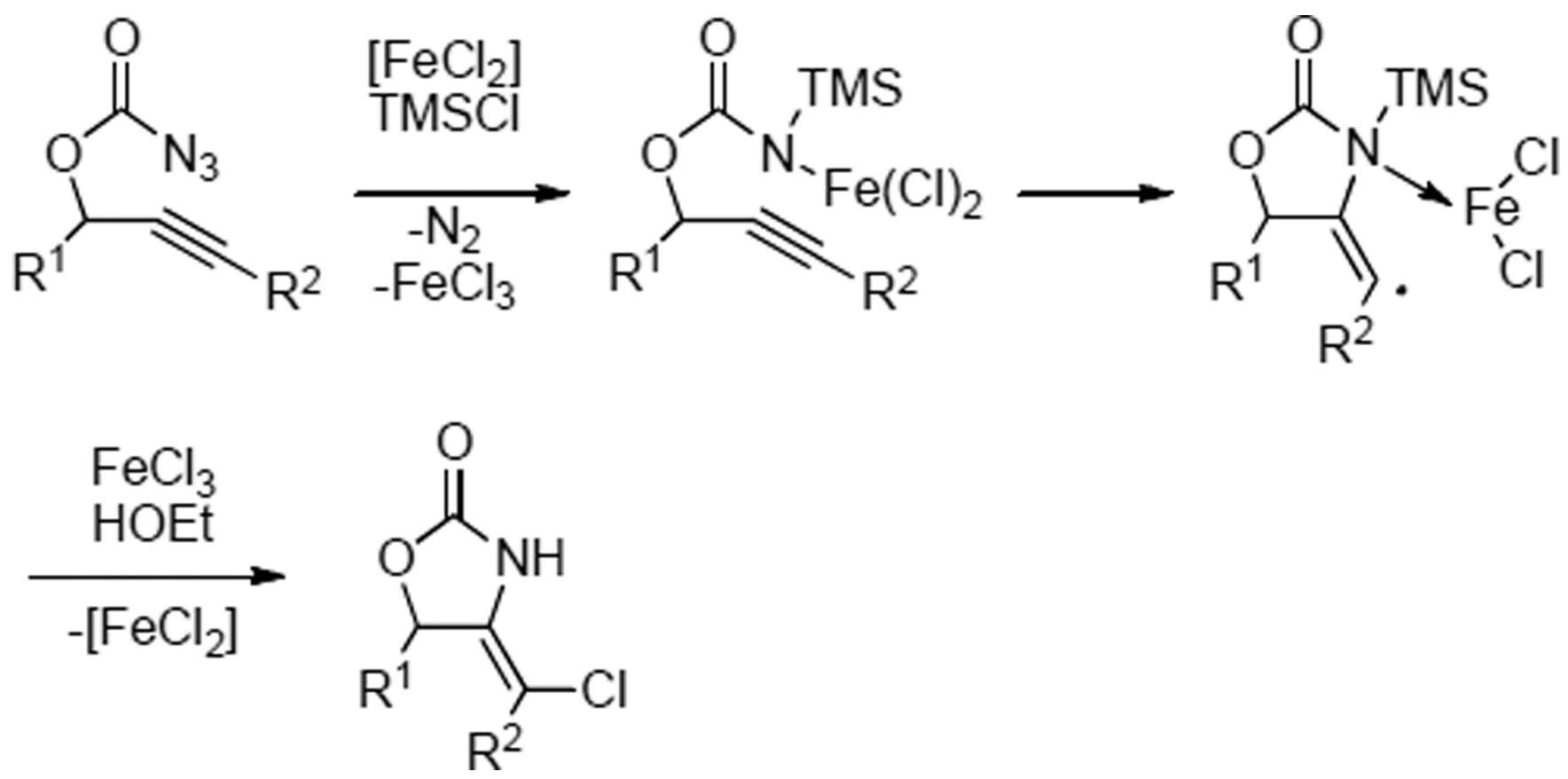

Scheme 2.

Proposed Mechanism for Alkyne Aminochlorination 
<smiles>[R]C#CC([R])=NN[R]</smiles><smiles>[R]c1nn([R1])c([R])c1[NH2+]</smiles><smiles>Cc1ccc(-c2c(F)c(C)nn2-c2ccccc2)cc1</smiles><smiles>CCCCc1c(F)c(C)nn1-c1ccccc1</smiles><smiles>Cc1nn(-c2ccccc2)c(C(C)(C)C)c1F</smiles>
$85 \%(A: B=7.2: 1)$ $78 \%(A: B=4.5: 1)$ $75 \%(A: B=5.1: 1)$<smiles>Cc1n[nH]c(-c2ccccc2)c1F</smiles><smiles>CCCCc1c(F)c(C)nn1-c1ccccc1</smiles><smiles>Fc1cnn(-c2ccccc2)c1-c1ccccc1</smiles>
$45 \%(A: B=2.1: 1)$ $78 \%(A: B=4.5: 1)$

Scheme 3.

Synthesis of Fluoropyrazoles 


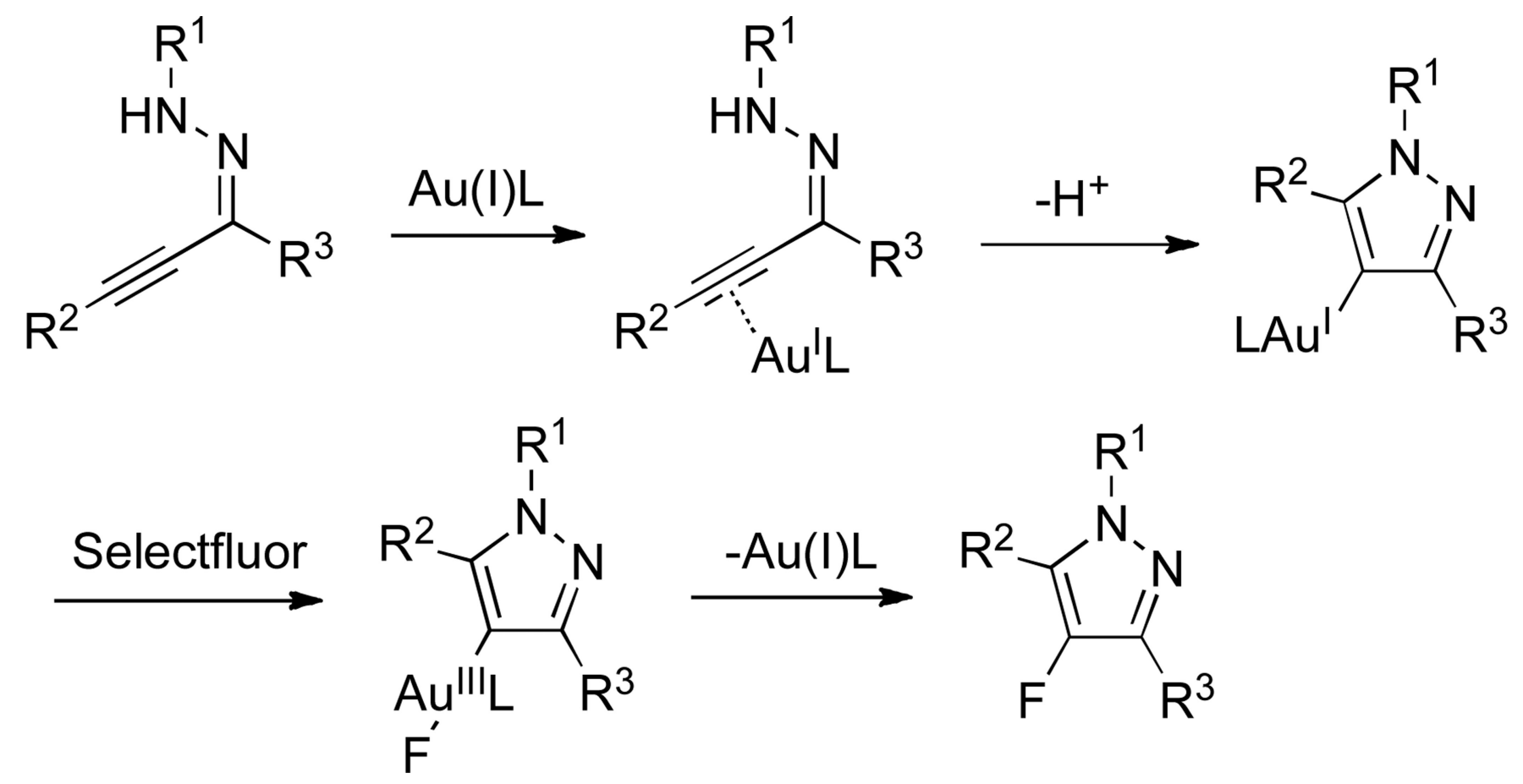

Scheme 4.

Proposed Aminofluorination Mechanism 
<smiles>[R]C(=C=C)C([R2])[NH2+][S-]</smiles>

(1.5 equiv)

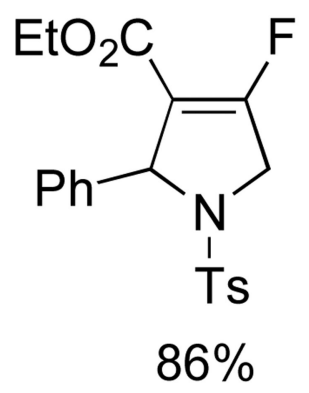

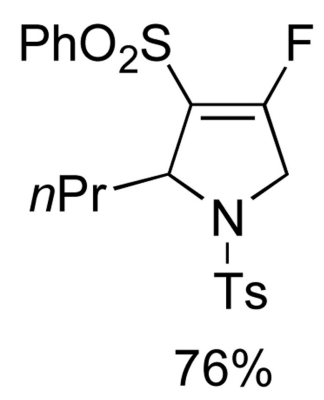
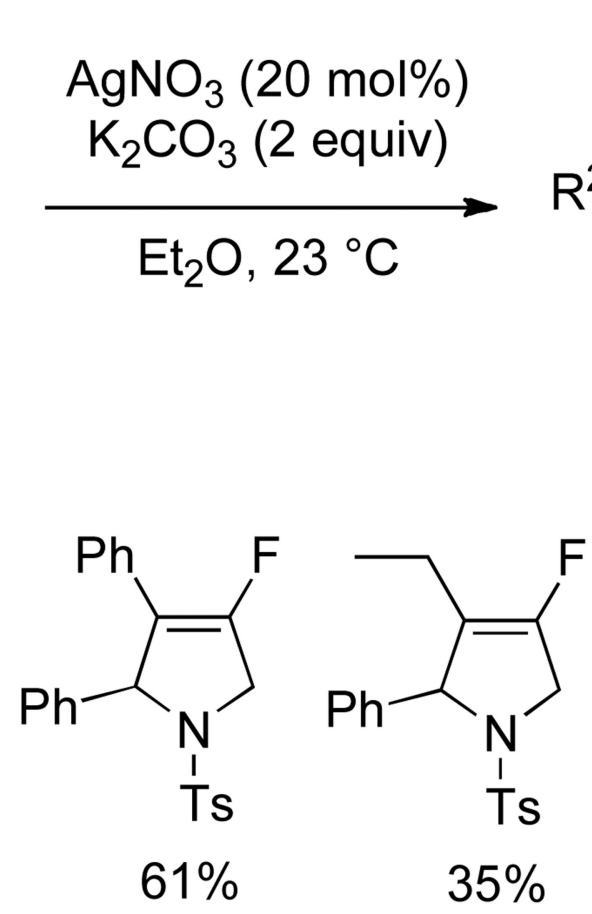
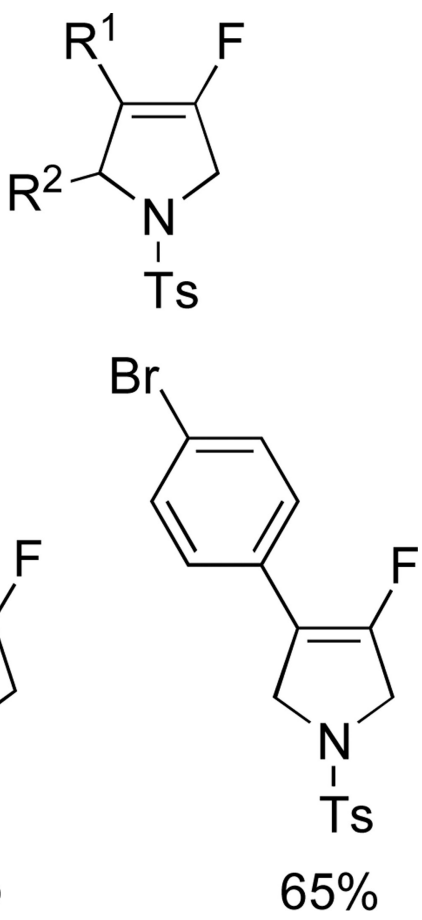

Scheme 5.

Silver-Catalyzed Synthesis of Unsaturated Fluoropyrrolidines 

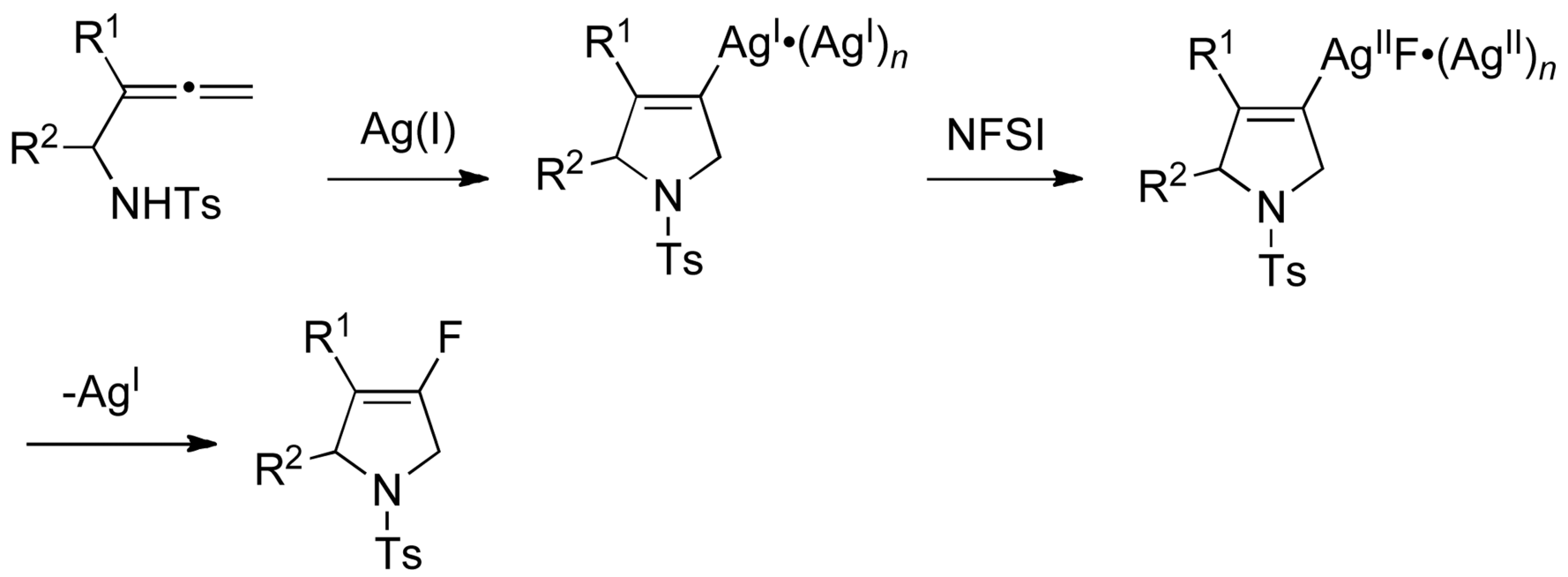

Scheme 6.

Proposed Aminofluorination Mechanism 
<smiles>[R]C#Cc1cc[R]([R])cc1/C=N\C(C)(C)C</smiles>
(1.5 equiv)<smiles>Fc1c(-c2ccccc2)ncc2ccccc12</smiles><smiles>CC(=O)OCCc1ncc2ccccc2c1F</smiles><smiles>Fc1c(C2=CCCCC2)ncc2ccccc12</smiles><smiles>[BH3-]</smiles>

$85 \%$

$56 \%\left(\right.$ at $30{ }^{\circ} \mathrm{C}$ )<smiles>O=C(O)N([Te])Cc1ncc2ccccc2c1F</smiles><smiles>Fc1c(-c2ccccc2)ncc2sccc12</smiles>

$79 \%$<smiles>CCCc1ncc2cc(OC)ccc2c1F</smiles><smiles>Fc1c(C2CC2)ncc2ccccc12</smiles><smiles>CCCc1ncc2cc(Cl)ccc2c1F</smiles>

Scheme 7.

Silver-Catalyzed Synthesis of 4-Fluoroisoquinolines 
<smiles>[R2]n1ccc2ccccc21</smiles>

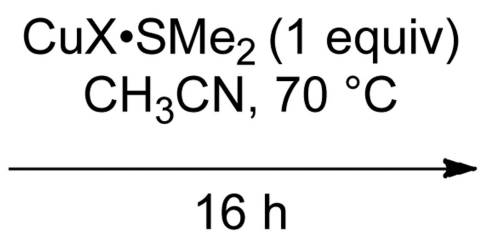<smiles>[X]c1c(N=C(c2ccccc2)c2ccccc2)n([R])c2ccccc12</smiles><smiles>O=S(=O)(O)c1ccccc1Cn1c(N=C(c2ccccc2)c2ccccc2)c(Br)c2ccccc21</smiles><smiles>Cn1c(N=C(c2ccccc2)c2ccccc2)c(Cl)c2ccccc21</smiles><smiles>Cn1c(N=C(c2ccccc2)c2ccccc2)c(I)c2ccccc21</smiles><smiles>COc1ccc2c(c1)c(Br)c(N=C(c1ccccc1)c1ccccc1)n2Cc1ccccc1</smiles>

Scheme 8.

$\mathrm{C}-\mathrm{H}$ Amination and C-H Bromination of Indoles 
<smiles>Brc1ccccc1Br</smiles><smiles>Cl[Mg]O[Ba]</smiles>

$\mathrm{Bn}$<smiles>CC(O)(Br)OC(=O)C(=NC1[C@H](C(Br)(Br)Br)c2ccccc2N1Cc1ccccc1)c1ccccc1</smiles><smiles>O=C(O)CCCC(=O)C1c2ccccc2N(Cc2ccccc2)[C@@H]1N=C(c1ccccc1)c1ccccc1</smiles><smiles>CC1(Cl)c2ccccc2N(Cc2ccccc2)[C@H]1N=C(c1ccccc1)c1ccccc1</smiles>

Scheme 9.

Proposed Indole Aminobromination Mechanism 


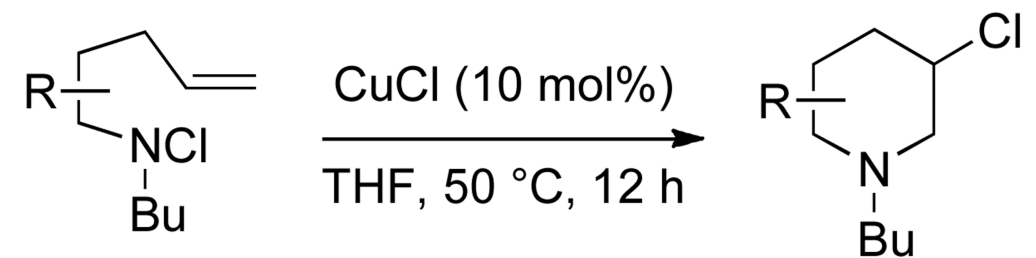<smiles>O=C(c1ccccc1)N1CCCC(Cl)C1</smiles><smiles>Cl[C@H]1CC[C@@H](c2ccccc2)N(Cc2ccccc2)C1</smiles><smiles>C[C@@H]1CC[C@@H](Cl)CN1Cc1ccccc1</smiles><smiles>C[C@H]1C[C@@H](Cl)CN(C)C1</smiles>

$\mathrm{Bu}$ $58 \%$

$$
\begin{gathered}
55 \% \\
d r=6: 1
\end{gathered}
$$

$77 \%$

$\mathrm{dr}=6: 1$<smiles>C[C@H]1CCN(Cc2ccccc2)C[C@H]1Cl</smiles>

$58 \%$ $\mathrm{dr}=5: 1$

\section{Proposed Mechanism}

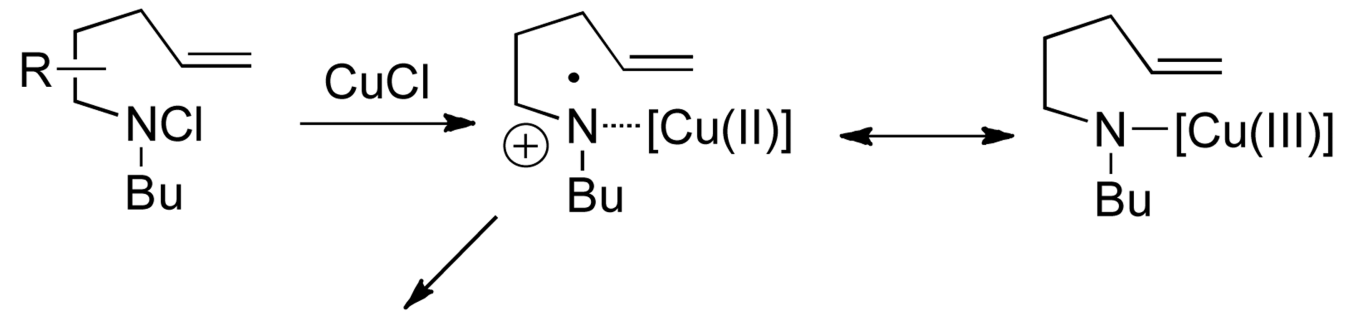<smiles>C[C@H]1CCCN1[13CH](Cl)Cl</smiles>
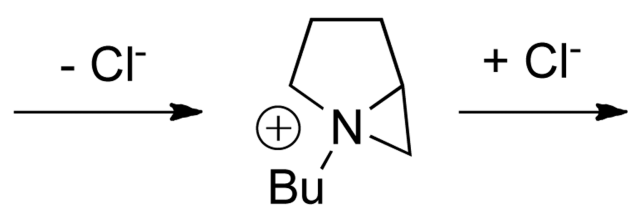<smiles>ClC1CCCN(Br)C1</smiles>

Scheme 10.

Copper-Catalyzed Endo-Selective Aminochlorination 


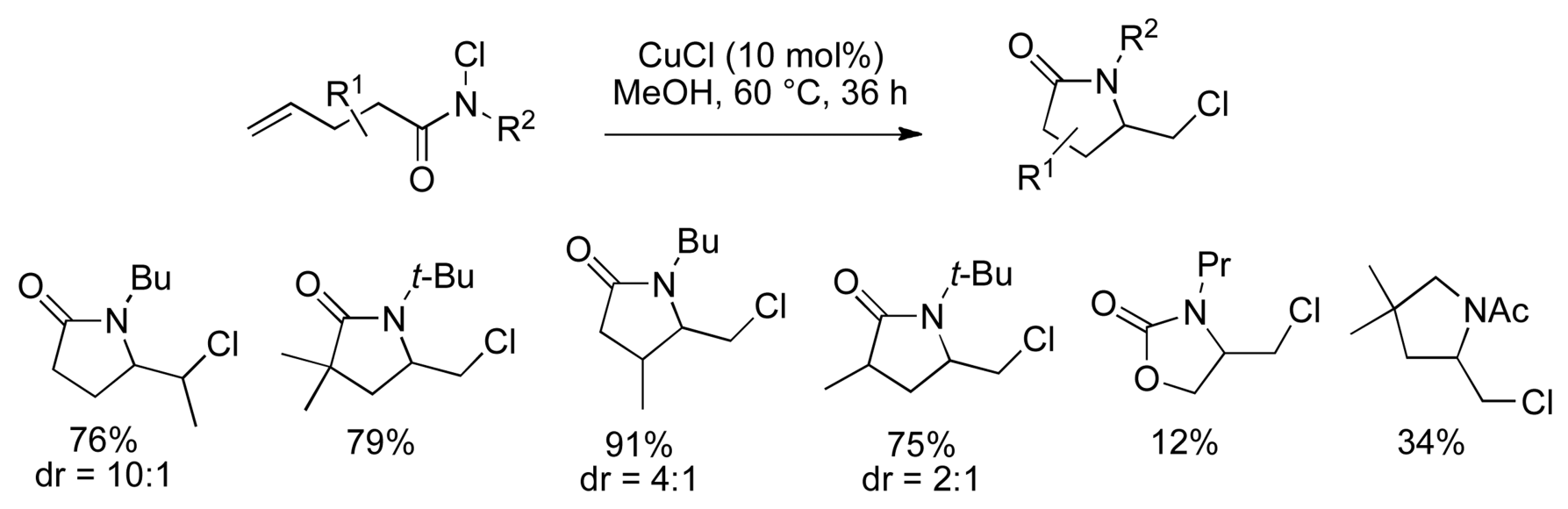

Scheme 11.

Copper-Catalyzed Exo-Selective Aminochlorination 

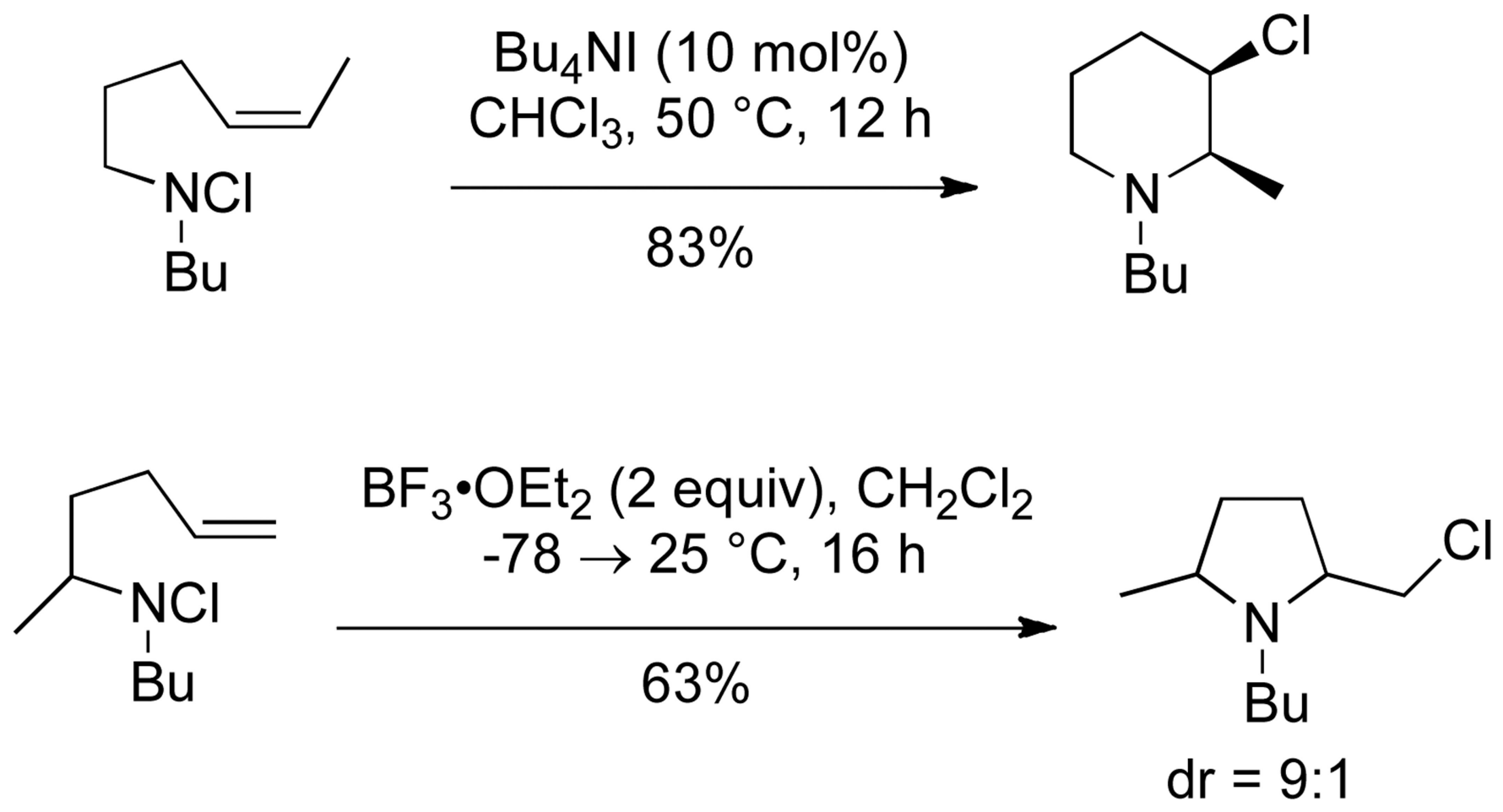

Scheme 12.

Iodide and Lewis acid-catalyzed aminochlorinations 

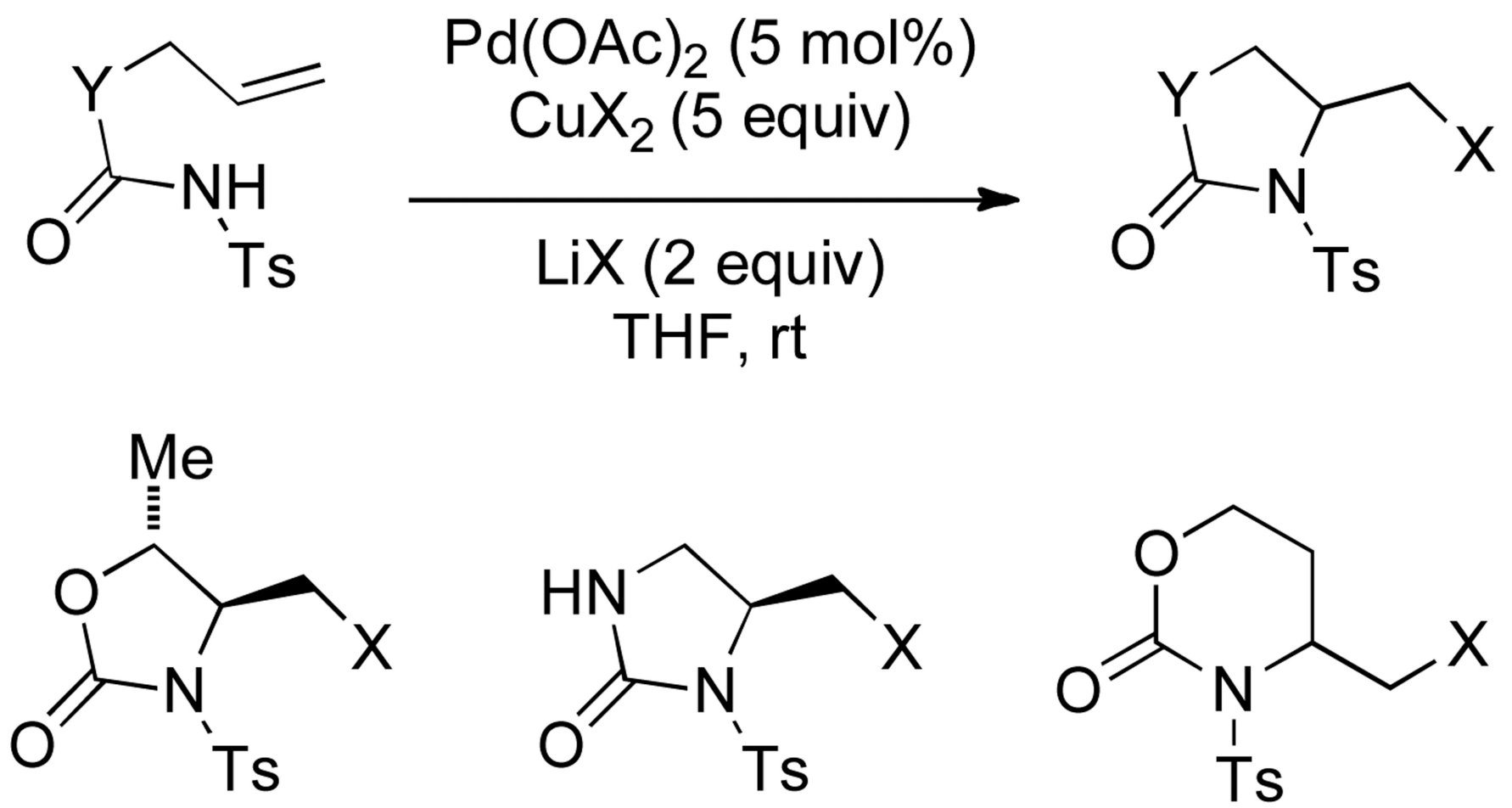

$X=\mathrm{Cl}, 66 \%$
$X=\mathrm{Br}, 65 \%$

$\mathrm{X}=\mathrm{Cl}, 86 \%$

$\mathrm{X}=\mathrm{Cl}, 77 \%$

$\mathrm{X}=\mathrm{Br}, 78 \%$

$\mathrm{X}=\mathrm{Br}, 68 \%$

Scheme 13.

Palladium-Catalyzed Aminohalogenation 


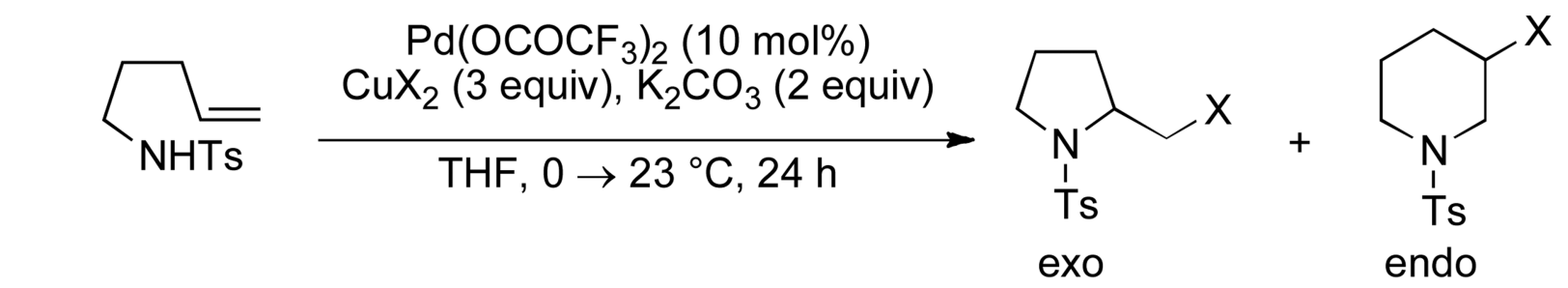<smiles>[X]CC1CCC(=O)N1[AsH-]</smiles>

$\mathrm{X}=\mathrm{Br}, 94 \%$ $\mathrm{X}=\mathrm{Cl}, 50 \%$ *

*with 5 equiv $\mathrm{CuCl}_{2}$ in $\mathrm{CH}_{3} \mathrm{CN}$<smiles>SC1Cc2ccccc2N1[Te]</smiles>

99\%, exo:endo $=3: 1$<smiles>[3H]N1CCCC(Br)C1</smiles>

$72 \%$, exo:endo $=1: 1.7$

\section{Proposed Mechanism}

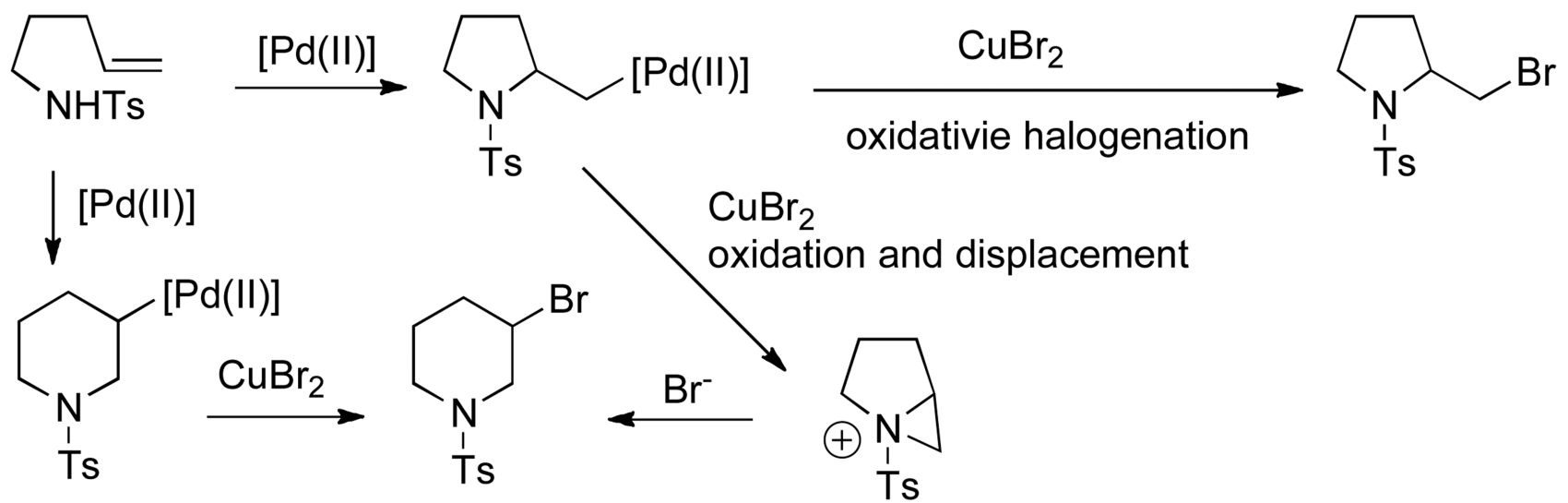

Scheme 14.

Aminohalogenation Scope and Proposed Mechanism 


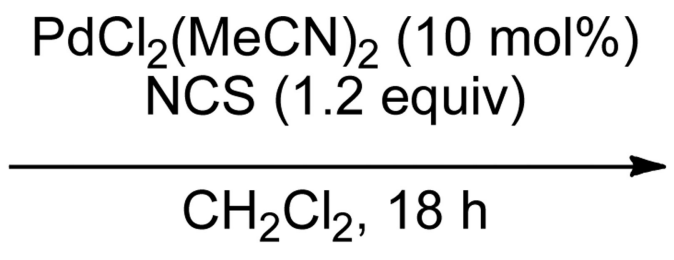

$\mathrm{R}$<smiles>O=C([Al-])N1c2ccccc2CC1CCl</smiles>

$63 \%$<smiles>O=C([O-])N1c2ccccc2CC1CCl</smiles>

$87 \%$<smiles>O=C([Te])N1CCCC1CCl</smiles>

$90 \%$<smiles>[R]N1CCCC1CCl</smiles><smiles>CC1(C)CN(C(=O)OCc2ccccc2)C(C)(CCl)C1</smiles>

$90 \%$

Scheme 15.

Palladium-Catalyzed Aminochlorination 


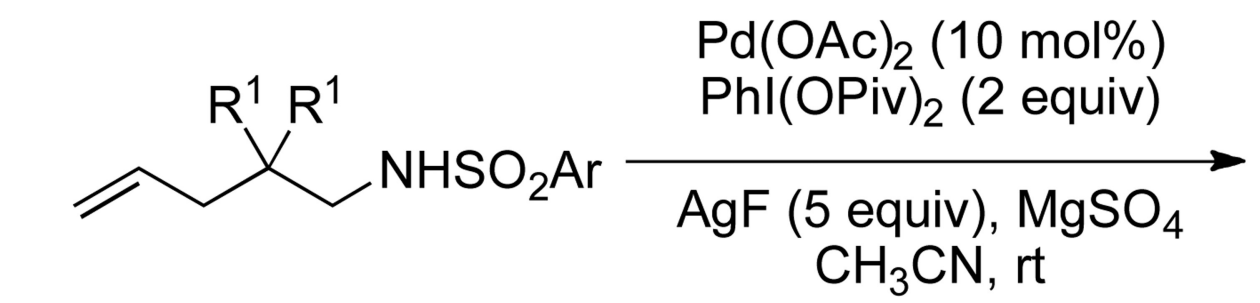<smiles>[R]C1([R])CC(F)CN(S(=O)(=O)O[Na])C1</smiles><smiles>CC1(C)CC(F)CN([Te])C1</smiles>

$84 \%$<smiles>CC1(C)CC(F)CN(S(C)(=O)=O)C1</smiles>

$74 \%$<smiles>FC1CC(c2ccccc2)CN([125I])C1</smiles>

$55 \%$
$\mathrm{dr}=2: 1$<smiles>FC1CCCN([As])C1</smiles>

$80 \%$<smiles>CC1(F)CN([Te])CC([P])(c2ccccc2)C1</smiles>

$80 \%$

\section{Labeling Experiment and Proposed Mechanism}<smiles>C=CCC(C)(C)C[Hg][As]C</smiles>

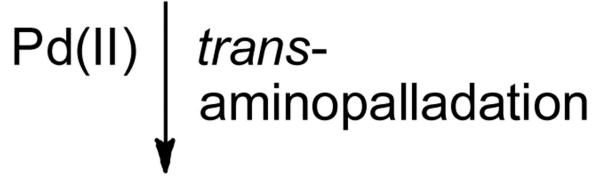

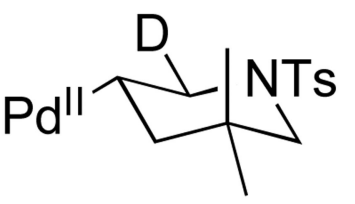

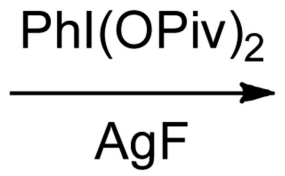

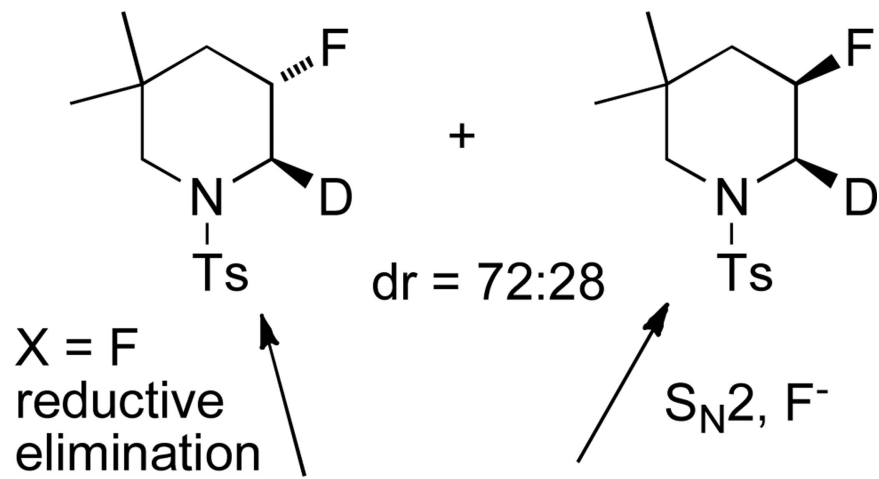
elimination

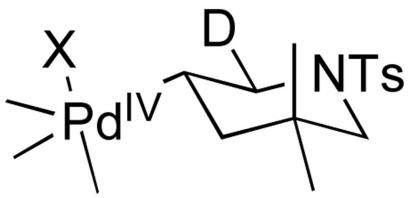

Scheme 16.

Aminofluorination Scope and Proposed Mechanism 


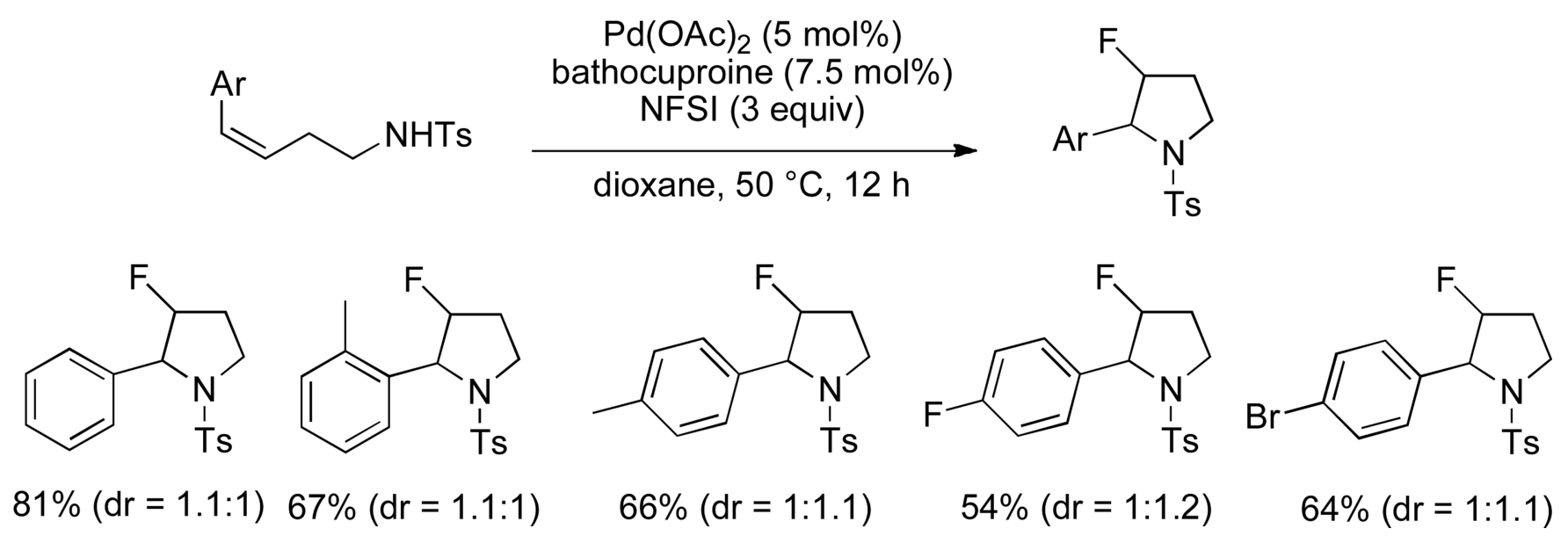

Scheme 17.

Pyrrolidines Via Endo-Selective Pd-Catalyzed Aminofluorination 
<smiles>[R]C([R])(CC=C)CN[AsH3-]</smiles>

$\mathrm{BF}_{3} \cdot \mathrm{OEt}_{2}$ $\mathrm{Phl}(\mathrm{OPiv})_{2}$

$\mathrm{HF} \cdot P$ yridine (10 equiv) $\mathrm{CH}_{2} \mathrm{Cl}_{2}$<smiles>[R]C1([R])CC(F)CN([As])C1</smiles><smiles>CC1(C)CC(F)CN([As])C1</smiles><smiles>F[C@H]1C[C@@H](Br)CN([Te])C1</smiles><smiles>F[C@H]1C[C@@H](c2ccccc2)CN([AsH2])C1</smiles><smiles>FC1CCCN([AsH2])C1</smiles>
$85 \%$ $63 \%$
$d r>99: 1$ $81 \%$ $\mathrm{dr}>99: 1$<smiles></smiles>

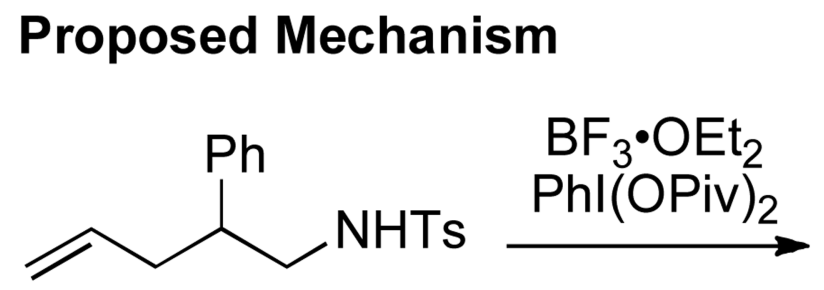

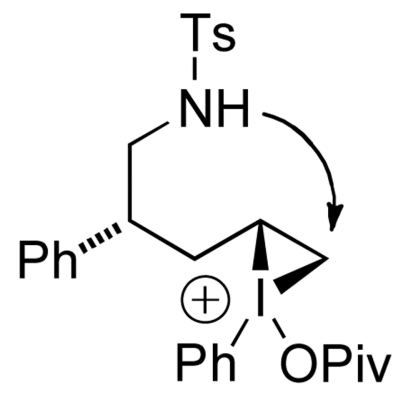<smiles>F[C@H]1C[C@@H](P)CN([Te])C1</smiles>

Scheme 18.

Hypervalent Iodine-Promoted Aminofluorination 


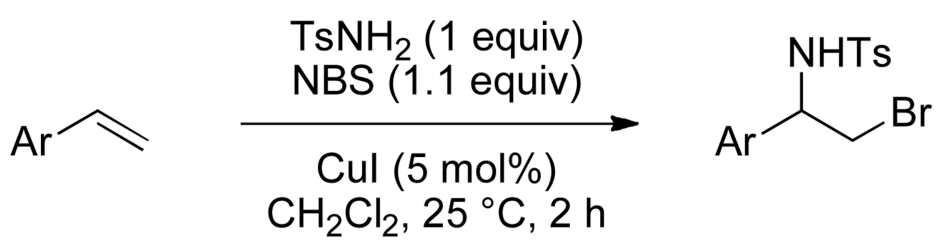<smiles>O=[W]OC(CBr)c1ccccc1</smiles><smiles>O=[N+]([O-])C(CBr)c1ccc(CCl)cc1</smiles>

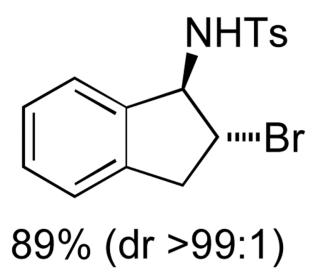

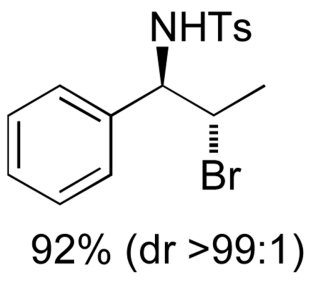<smiles>[PH3-][C@H]1CCCC[C@H]1Br</smiles>

Scheme 19.

Copper-Catalyzed Aminobromination of Styrenes 


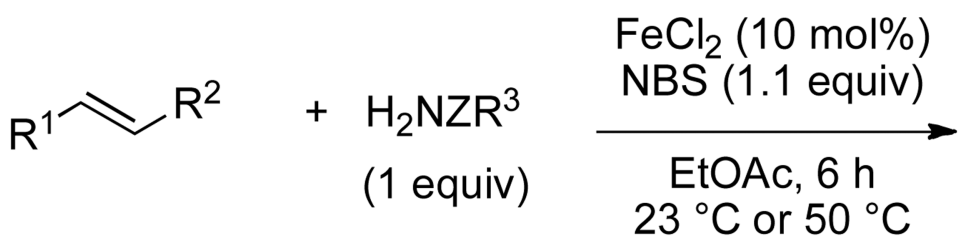<smiles>[R]NC([R])C([R])Br</smiles><smiles>O=C(N[C@@H]1CCC[C@H]1Br)c1ccccc1</smiles>

$80 \%$<smiles>Br[C@@H]1CCC[C@H]1N[I-]</smiles>

$83 \%$<smiles>O=C(NC(CBr)c1ccccc1)c1ccccc1</smiles><smiles>O=C(N[C@H](c1ccccc1)[C@@H](Br)c1ccccc1)c1ccccc1</smiles><smiles>O=C(N[C@@H]1CCC[C@H]1Br)c1ccc([N+](=O)[O-])cc1</smiles>

Scheme 20.

Iron-Catalyzed Intermolecular Aminobromination 
<smiles>C=Cc1c#[R]ccc1</smiles>

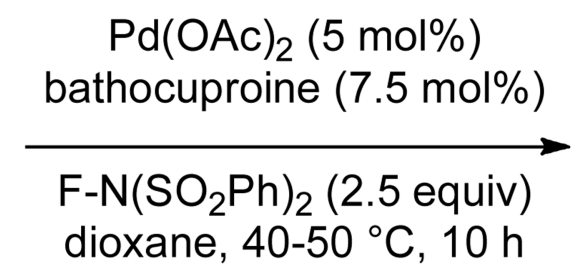<smiles>[R]OS(=O)(=O)NC(CF)c1cc#[R]cc1</smiles><smiles>O=[N+]([O-])[O-]</smiles>

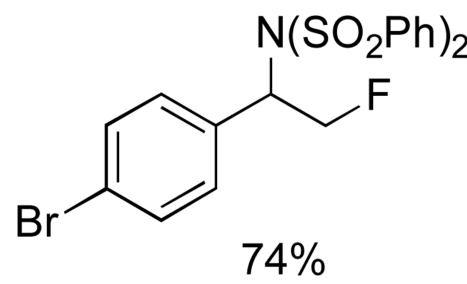<smiles>O=C([O-])Oc1ccc(C(CF)NS(=O)(=O)O)cc1</smiles><smiles>O=S(=O)(O)N[C@@H]1c2ccccc2C[C@@H]1F</smiles>

\section{Proposed Mechanism}

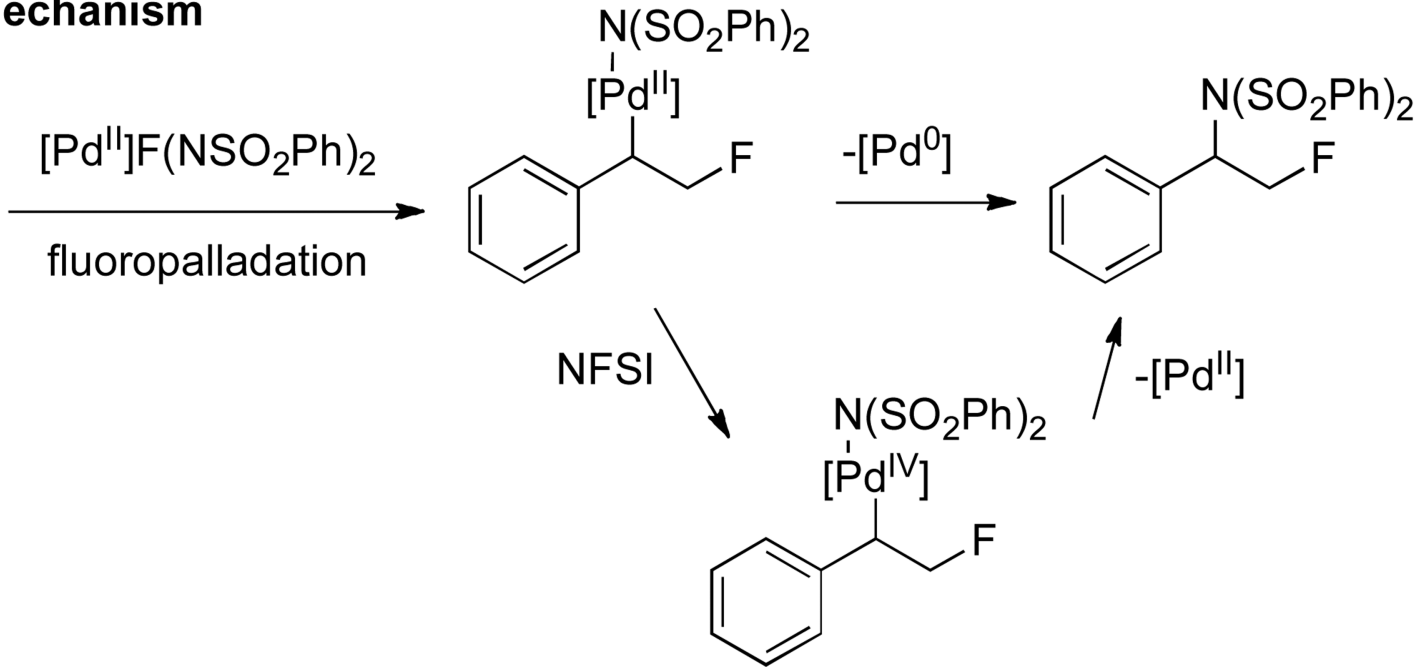

Scheme 21.

Pd-Catalyzed Aminofluorination of Styrenes 
<smiles>C=Cc1ccccc1</smiles><smiles>[R]C1C=CCCC1</smiles>

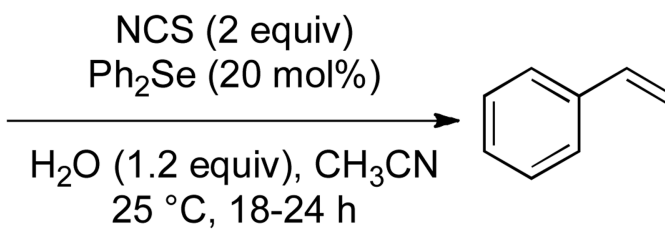

or<smiles>[R]C1CCC[C@@H](NC(C)=O)[C@H]1Cl</smiles><smiles>CC(=O)NC(CCl)c1ccccc1</smiles><smiles>CC(=O)N[C@@]1(C)CCCC[C@H]1Cl</smiles><smiles>CC(=O)N[C@@H]1CCC[C@@H](OC(C)=O)[C@H]1Cl</smiles>
$76 \%$<smiles>CC(=O)N[C@H]1CCC[C@@H]([N+](=O)[O-])[C@H]1Cl</smiles>

Scheme 22.

Selenide-catalyzed Aminochlorination 

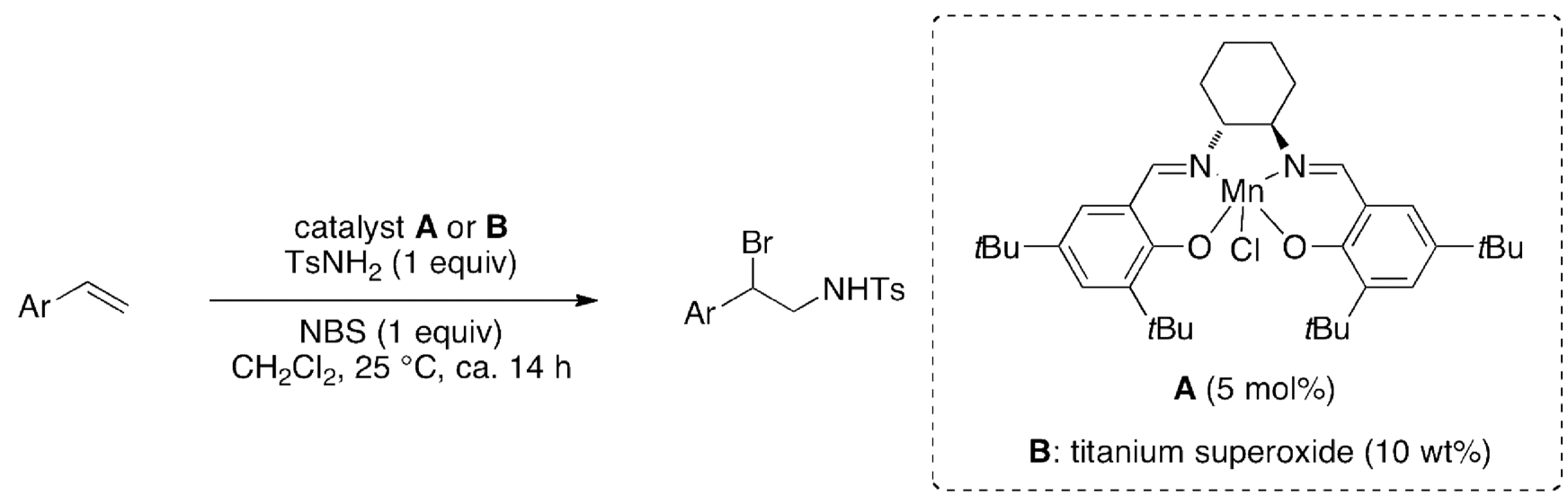<smiles>[18F]NCC(Br)c1ccccc1</smiles>

A: $97 \%$

B: $81 \%$<smiles>[AsH2]NCC(Br)c1ccc(Br)cc1</smiles>

B: $69 \%$<smiles>[18F]CC(Br)c1ccc(CCl)cc1</smiles>

A: $95 \%$

B: $67 \%$<smiles>BrC1c2ccccc2C[C@H]1N[Pb]</smiles>

A: $90 \%(d r>99: 1)$

B: $80 \%(d r>99: 1)$<smiles>[PH3-][NH2+]C1CCCCC1Br</smiles>

B: $65 \%(>99: 1)$

Scheme 23.

Anti-Markovnikov Aminohalogenation 

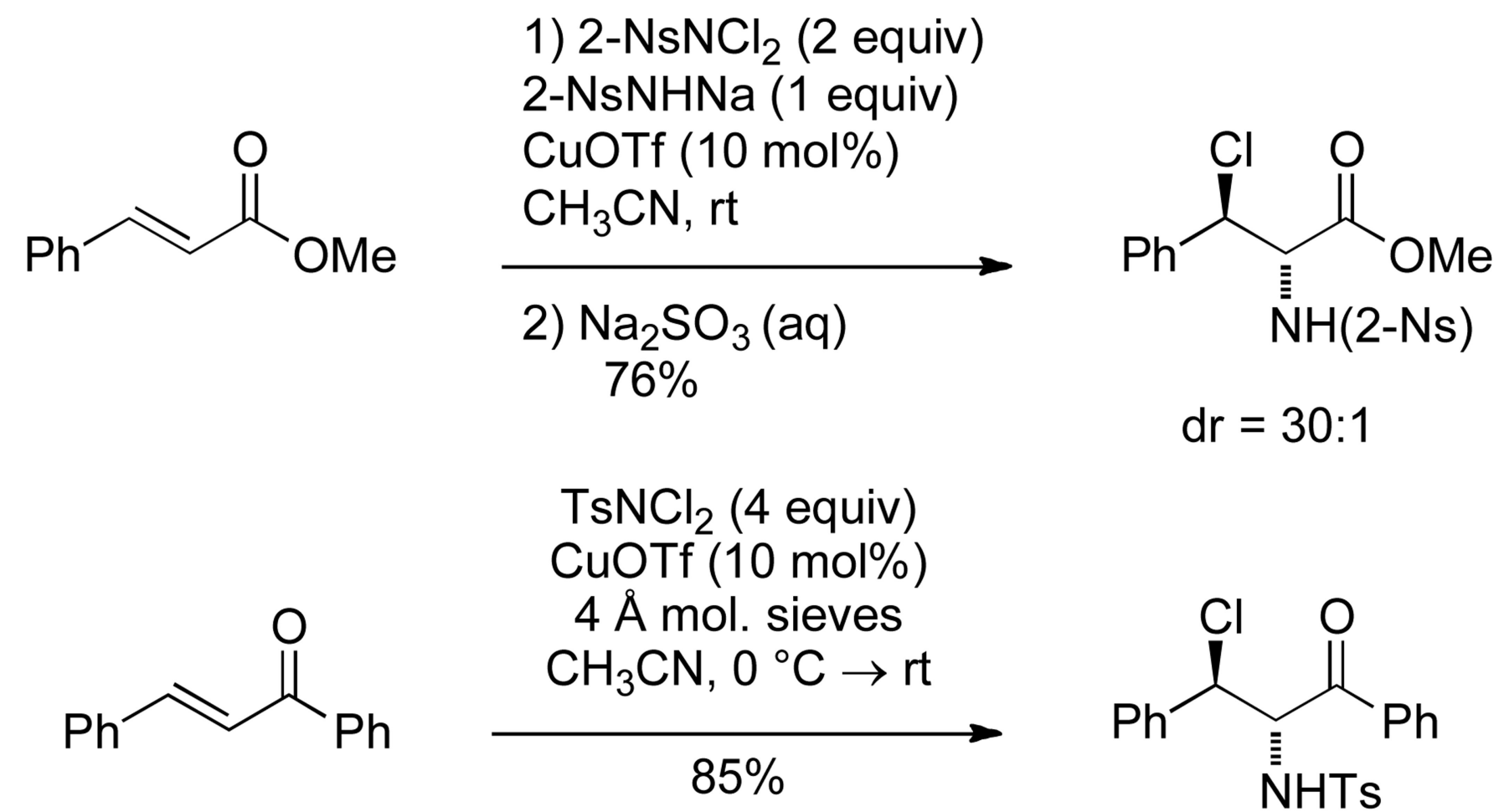

1) $2-\mathrm{NsNCl}_{2}$ (2 equiv) 2-NsNHNa (1 equiv) CuOTf (10 mol\%) $\mathrm{CH}_{3} \mathrm{CN}$, rt

2) $\mathrm{Na}_{2} \mathrm{SO}_{3}(\mathrm{aq})$ $76 \%$

$d r=30: 1$

$$
d r=9: 1
$$

Scheme 24.

Aminohalogenation of $a, \beta$-Unsaturated Esters and Ketones 


\section{Acid Catalyzed}

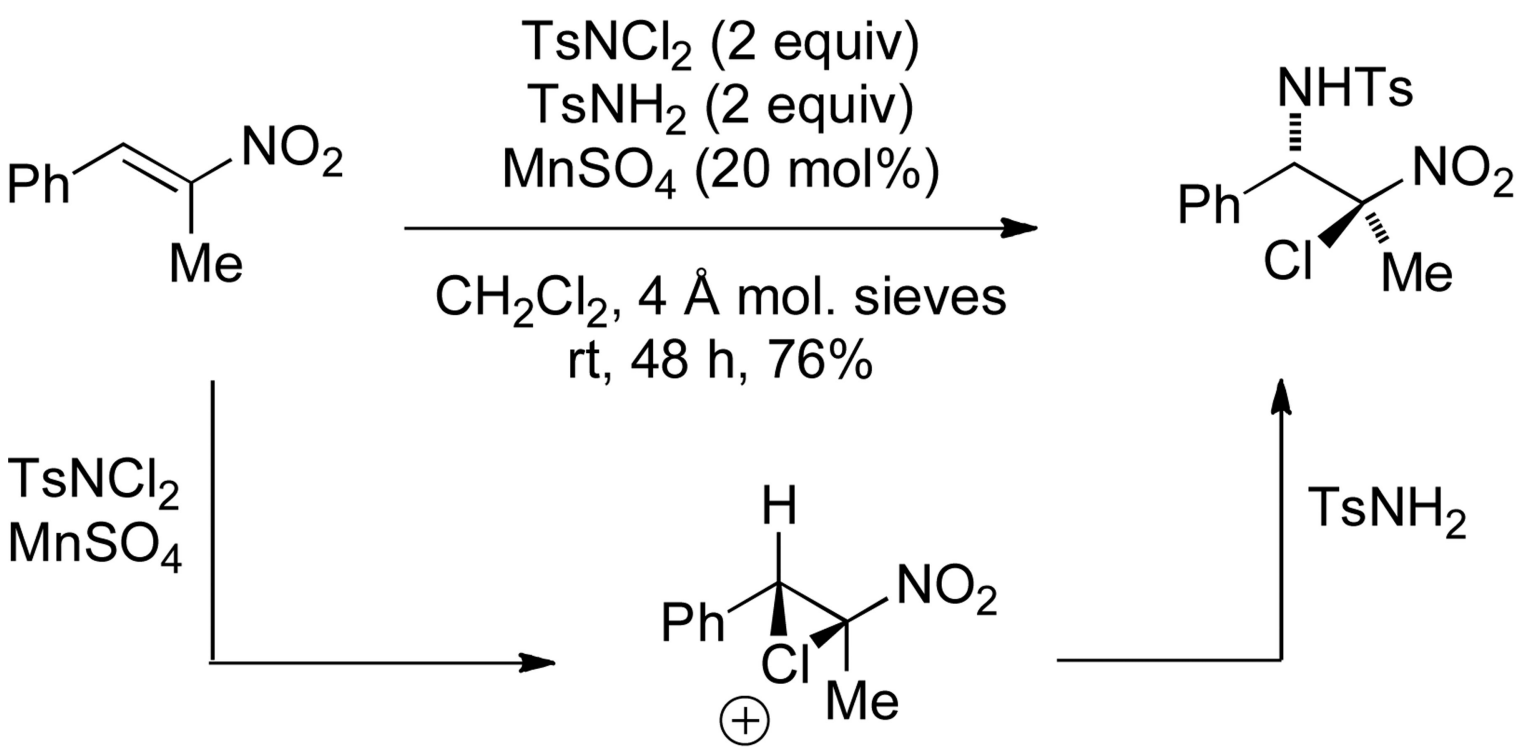

\section{Base Catalyzed}

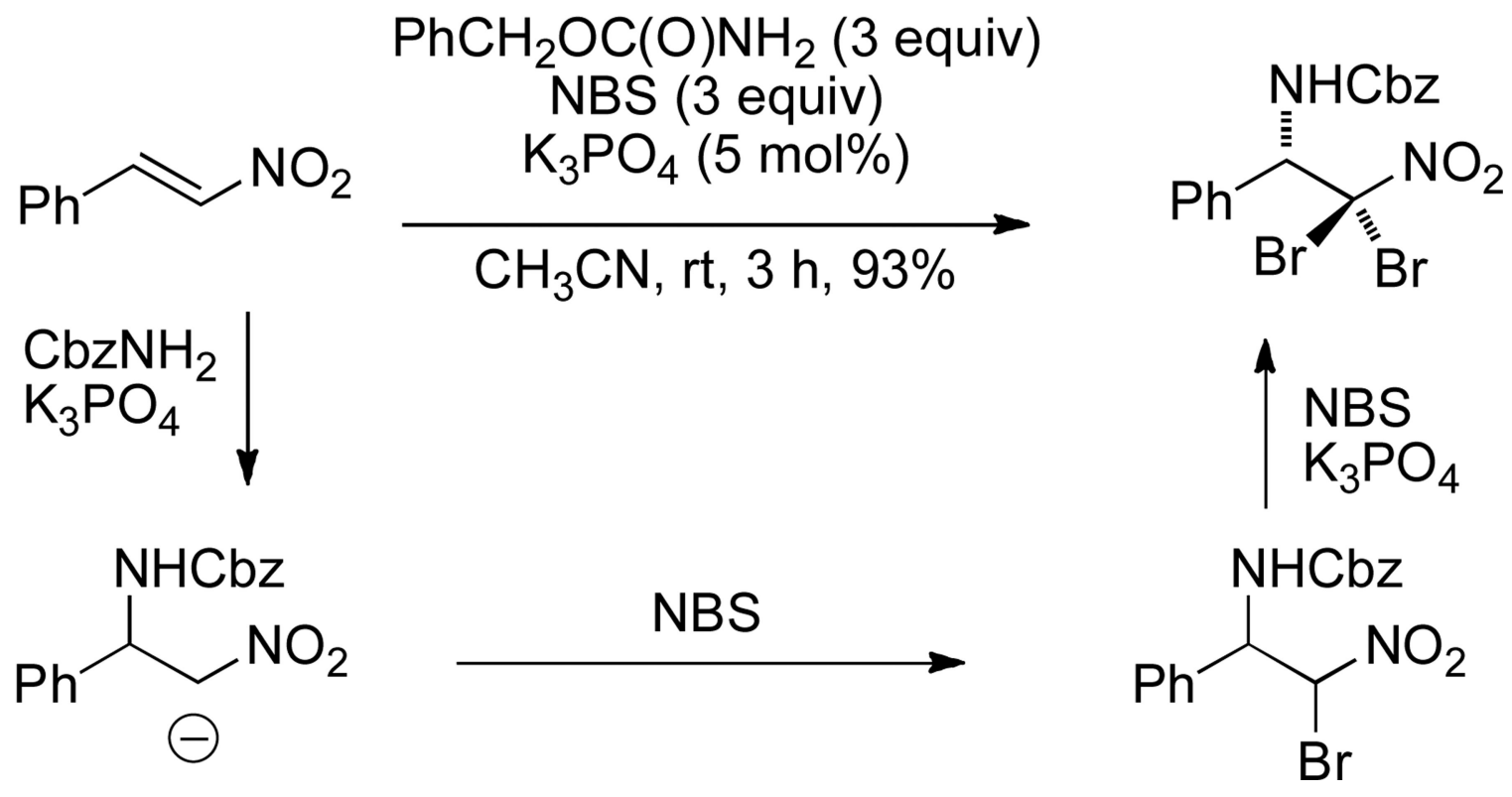

Scheme 25.

Aminohalogenation of Nitroalkenes 

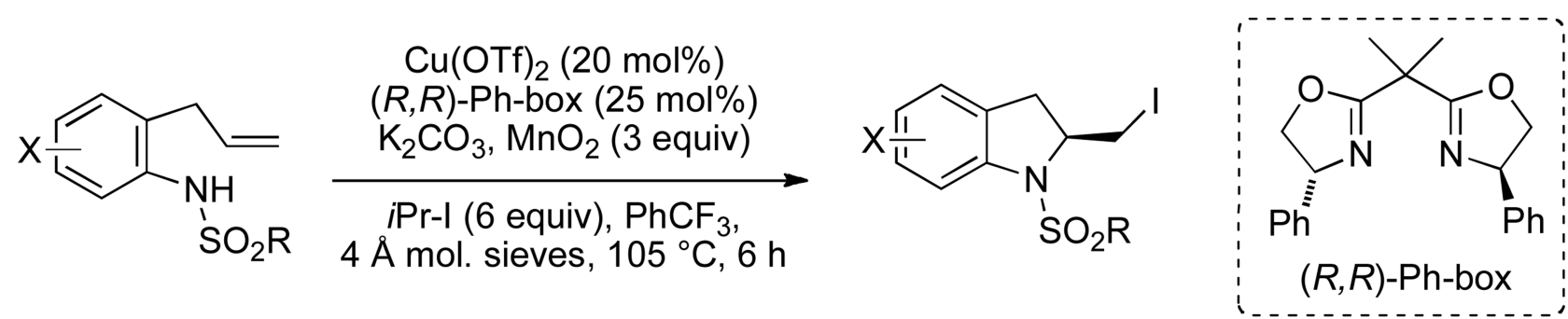<smiles>Cc1ccc2c(c1)C[C@H](CI)N2[13S]</smiles><smiles>Fc1ccc2c(c1)C[C@H](CI)N2[12F]</smiles>

$85 \%, 90 \%$ ee
$80 \%, 89 \%$ ee

Scheme 26.

Enantioselective Synthesis of Indolines<smiles>COc1ccc2c(c1)C[C@H](CI)N2[13S]</smiles>

$72 \%, 87 \%$ ee<smiles>CCCOS(=O)(=O)N1c2ccccc2C[C@H]1CI</smiles>

$85 \%, 82 \%$ ee 

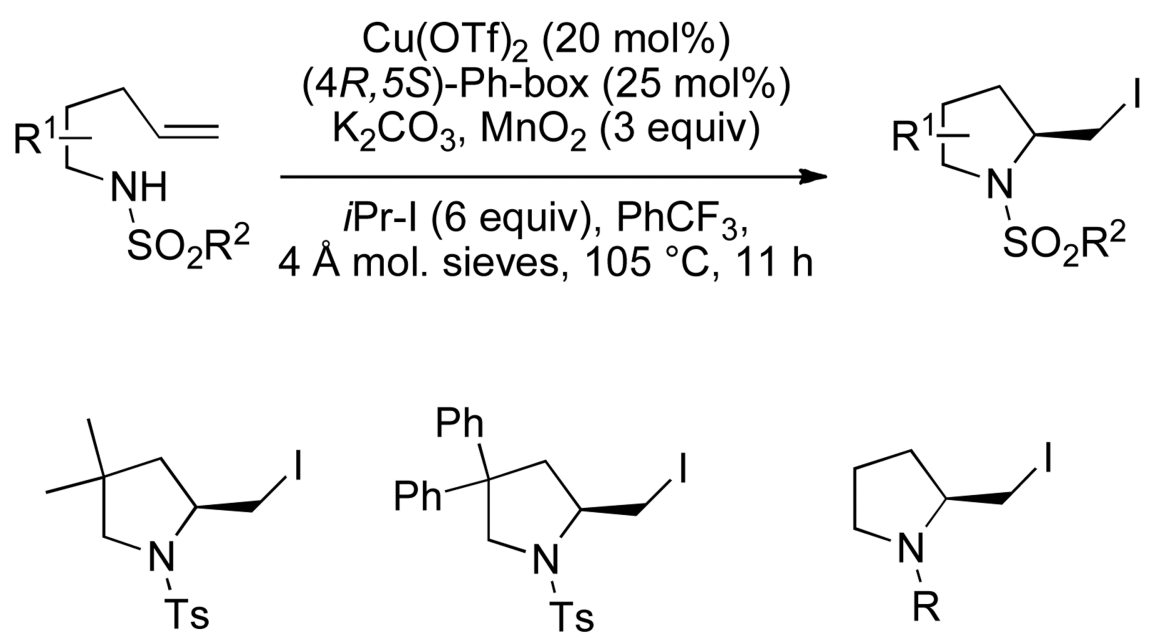

$81 \%, 88 \%$ ee<smiles>[3H]N1CC(c2ccccc2)(c2ccccc2)C[C@H]1CI</smiles>

$81 \%, 88 \%$ ee<smiles>[R]N1CCC[C@H]1CI</smiles>

$\mathrm{R}=3,5-$ di-tBu- $\mathrm{C}_{6} \mathrm{H}_{3} \mathrm{SO}_{2}$ $85 \%, 88 \%$ ee
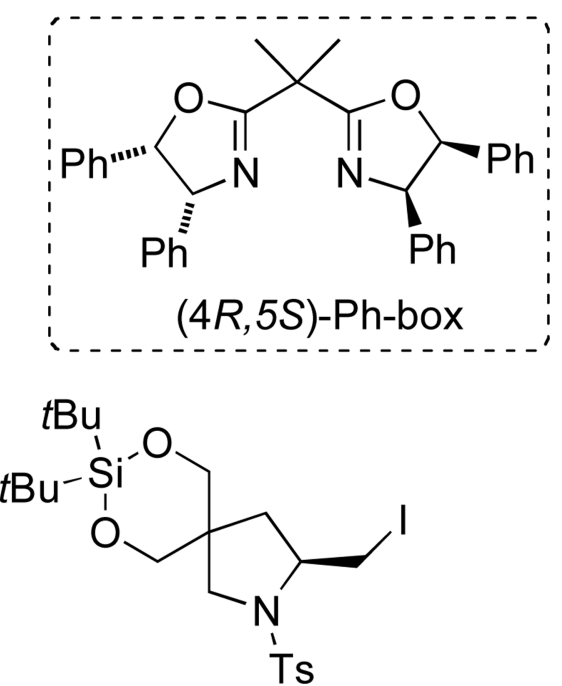

$78 \%, 92 \%$ ee

Scheme 27.

Enantioselective Synthesis of Pyrrolidines 

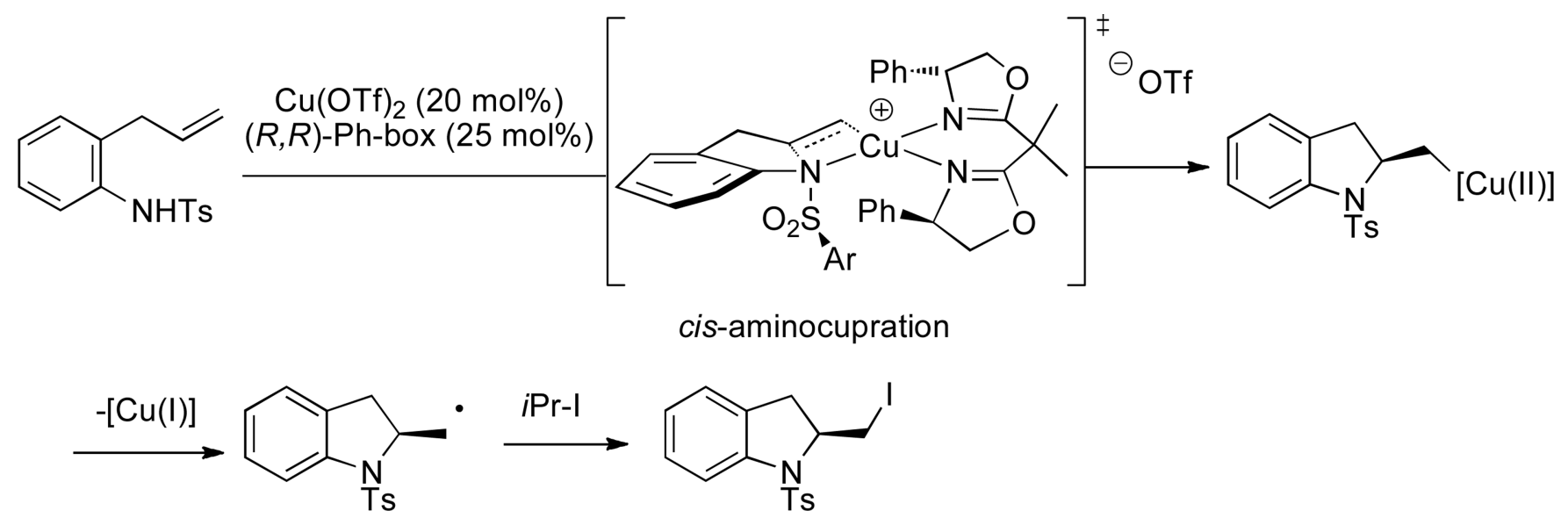

Scheme 28.

Proposed mechanism involving cis-aminocupration 


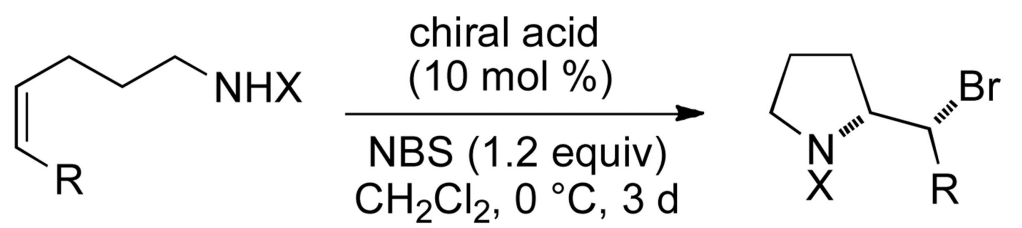

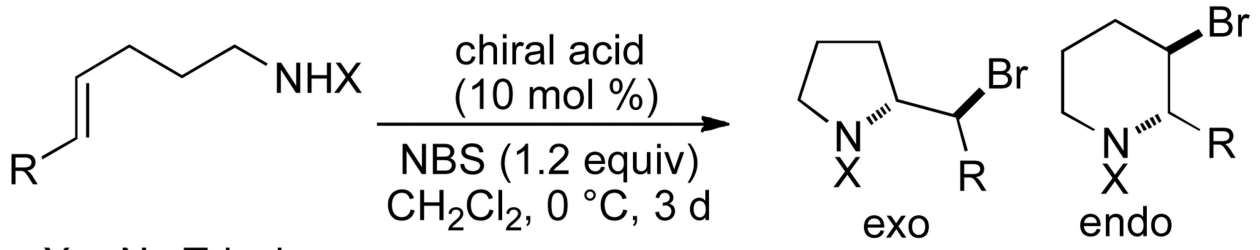<smiles>[R]Oc1c([R])cc2ccccc2c1-c1c(OP(=O)(O)O)c([R])cc2ccccc12</smiles>

$\mathrm{X}=\mathrm{Ns}$, Trisyl

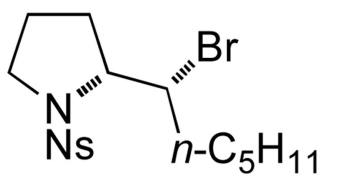<smiles>C[C@H](Br)[C@H]1CCCN1[AlH2]</smiles><smiles>[AlH2]N1CCC[C@H]1[C@@H](Br)CBr</smiles><smiles>CC(Br)C1CCCN1[AsH3]</smiles><smiles>CCCCCCCCC1(C)CCCN1S(C)(=O)=O</smiles>

$90 \%, 90 \%$ ee

$76 \%, 81 \%$ ee

$62 \%, 85 \%$ ee

$72 \%, 58 \%$ ee $14: 1$ (exo:endo)

$59 \%, 74 \%$ ee

Scheme 29.

Chiral Phosphoric Acid-Catalyzed Aminobromination 


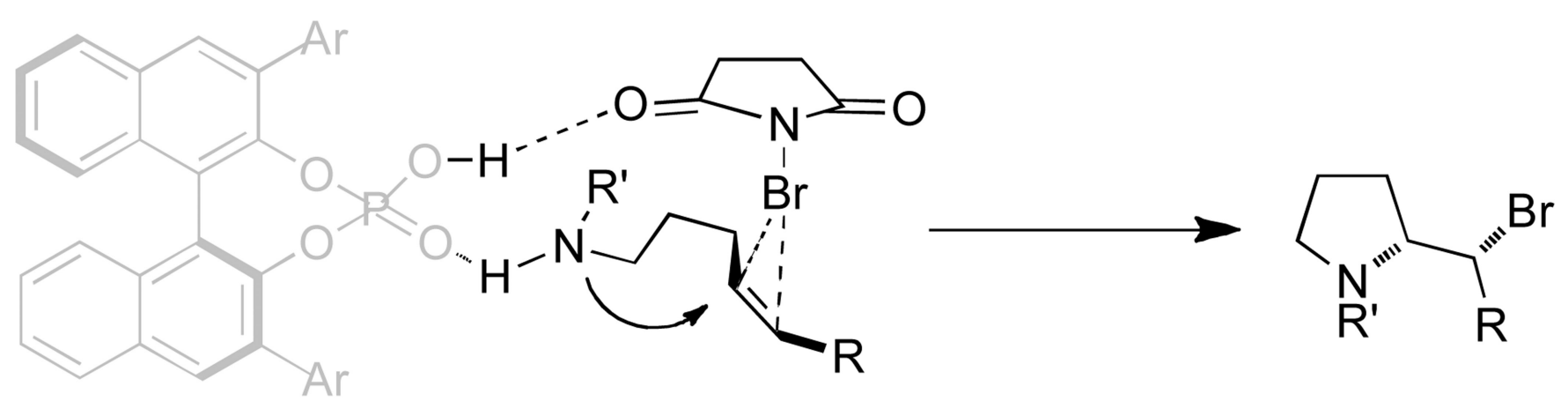

\section{$\operatorname{Ar}=2,4,6-\mathrm{PPr}_{3} \mathrm{C}_{6} \mathrm{H}_{2}$}

Scheme 30.

Transition State Model for Enantioselective Aminohalogenation 
<smiles>[R]C(=C)CCCNNS(C)(=O)=O</smiles>

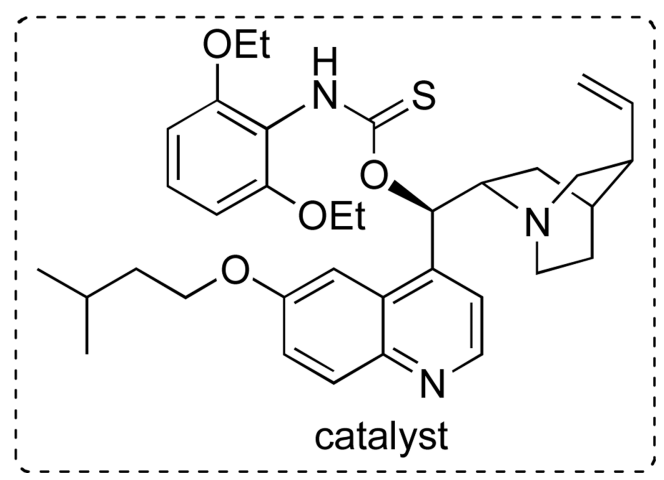

Scheme 31.

Amino-Thiocarbamate Catalyzed Bromoaminocyclization of Alkenes 
<smiles>[R]C(=C)CCCN[SH2+]</smiles><smiles>[R]C(=C)CCC[Nb](=O)[O-]</smiles>

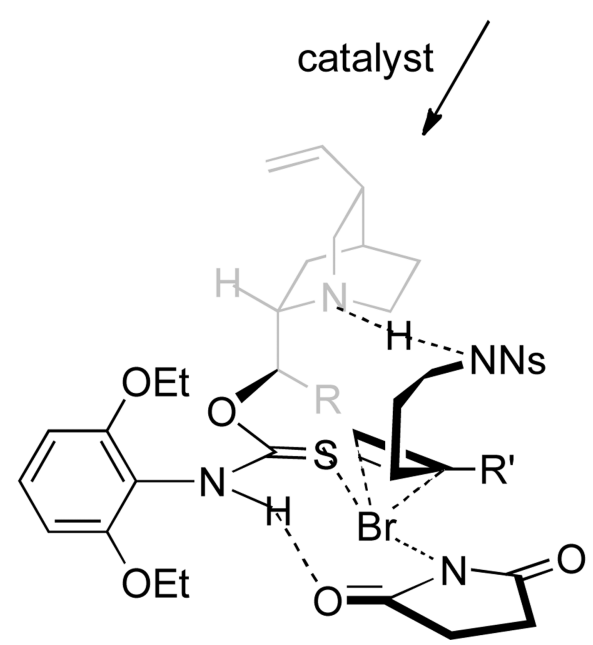
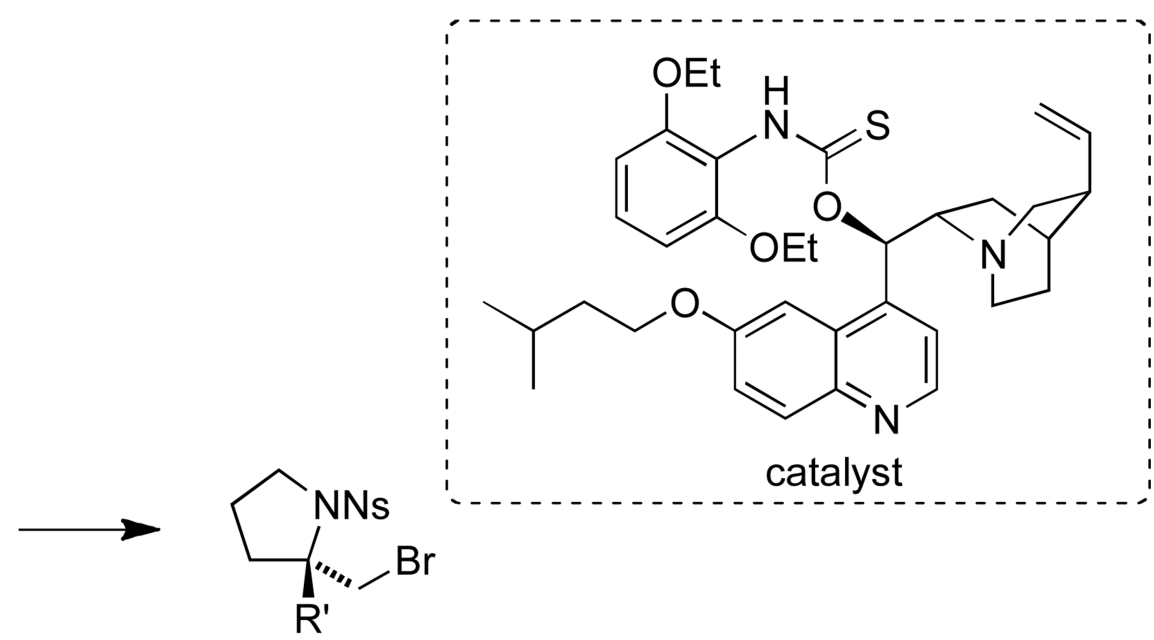

Scheme 32.

Proposed Mechanism of Amino-Thiocarbamate Catalysis 


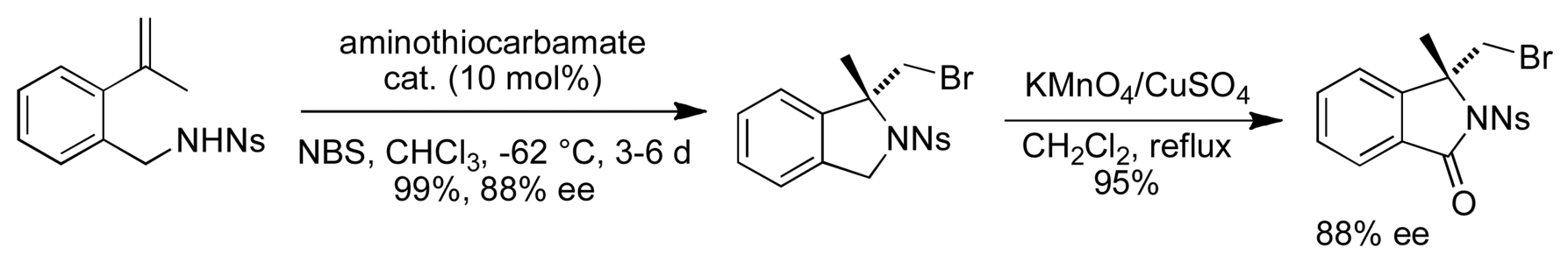

Scheme 33.

Formation of Isoindolines and Oxidation to Isoindolinone 
<smiles>[R]C(=C)CCOC(=N)C(Cl)(Cl)Cl</smiles>

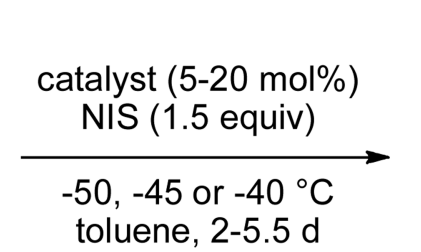<smiles>[R][C@]1(CI)CCOC(C([3H])(Cl)Cl)=N1</smiles>

$\mathrm{R}=4-\mathrm{F}-\mathrm{C}_{6} \mathrm{H}_{4}$

$86 \%, 90 \%$ ee

$4-\mathrm{Cl}-\mathrm{C}_{6} \mathrm{H}_{4}$

$87 \%, 95 \%$ ee

$4-\mathrm{MeOC}(\mathrm{O}) \mathrm{C}_{6} \mathrm{H}_{4} \quad 34 \%, 96 \%$ ee

$\mathrm{Ph}$

$79 \%, 90 \%$ ee

$\mathrm{CH}_{2} \mathrm{CH}(\mathrm{Me})_{2}$

$96 \%, 73 \%$ ee

Scheme 34.

Enantioselective Aminoiodination of Alkenyl Trichloroacetimidates 


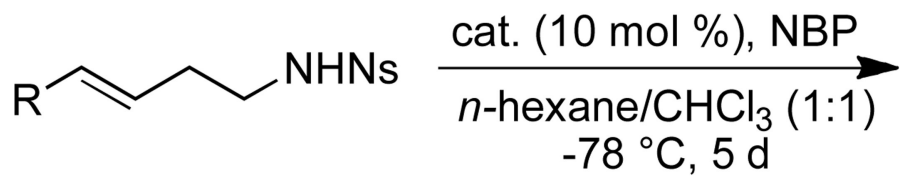

$\mathrm{R}=4-\mathrm{FC}_{6} \mathrm{H}_{4}$ 4- $\mathrm{MeC}_{6} \mathrm{H}_{4}$ 2-napthyl 3-thienyl Et<smiles>[R]C1[C@H](Br)CCN1S(C)(=O)=O</smiles>
$89 \%, 91 \%$ ee $95 \%, 85 \%$ ee $97 \%, 88 \%$ ee $84 \%, 84 \%$ ee $85 \%, 86 \%$ ee

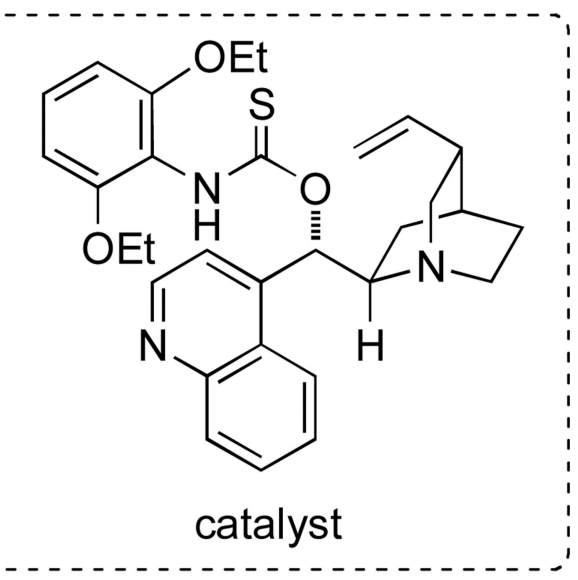

Scheme 35.

Scope for the Amino-Thiocarbamate Catalyzed Endo-Bromoaminocyclization 
<smiles>[R]NCCc1cn(C)c2ccc([R])cc12</smiles>

$\mathrm{F}-\mathrm{N}\left(\mathrm{SO}_{2} \mathrm{Ph}\right)_{2}(1.2$ equiv) $(\mathrm{DHQ})_{2} \mathrm{PHAL}(20 \mathrm{~mol} \%)$

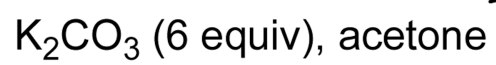
$-78^{\circ} \mathrm{C}, 15 \mathrm{~h}$

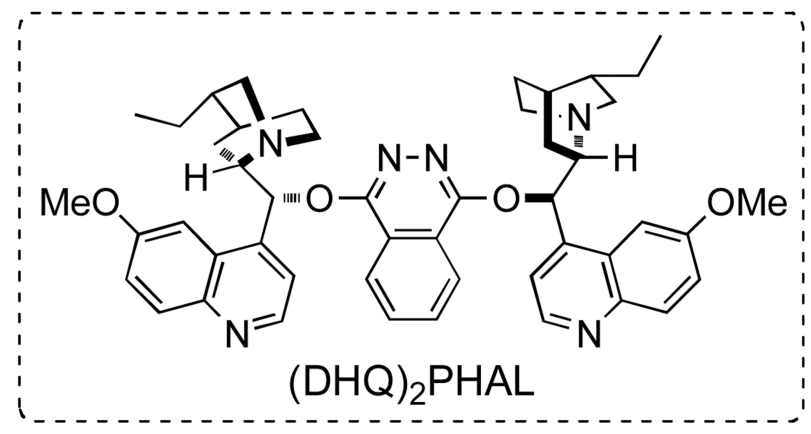

Scheme 36.

Enantioselective aminofluorination of tryptamines<smiles>[R1]c1ccc2c(c1)[C@@]1(F)CCN([R])[C@@H]1N2C</smiles>

$R^{1}=H, R^{2}=$ Ts: $59 \%, 64 \%$ ee $\mathrm{R}^{1}=\mathrm{OMe}, \mathrm{R}^{2}=\mathrm{Ts}: 51 \%, 70 \%$ ee $\mathrm{R}^{1}=\mathrm{H}, \mathrm{R}^{2}=$ COMe: $95 \%, 80 \%$ ee $R^{1}=H, R^{2}=$ Boc: $70 \%, 78 \%$ ee 


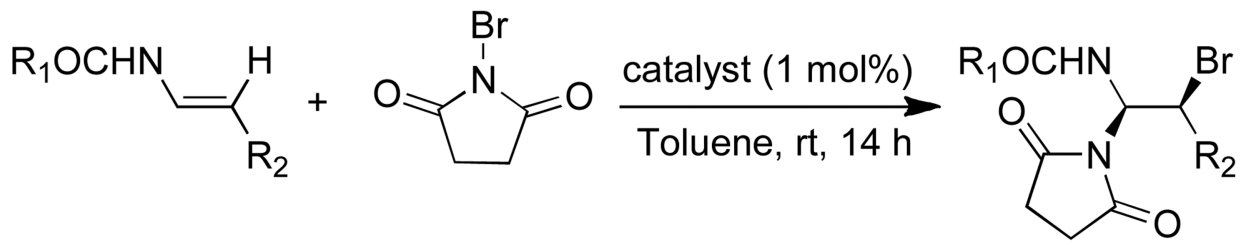<smiles></smiles><smiles>CCC(Br)[C@H](NC(=O)OCc1ccccc1)N1C(=O)CCC1=O</smiles><smiles>C=CC(=O)N[C@H](NC(=O)OCc1ccccc1)[C@H](Br)C(C)C</smiles><smiles>O=C(N[C@H]([C@H](Br)C1CC1)N1C(=O)CCC1=O)OCc1ccccc1</smiles><smiles>O=C(N[C@H]([C@H](Br)COc1ccccc1)N1C(=O)CCC1=O)OCc1ccccc1</smiles><smiles>CC(C)(Br)[C@H](NC(=O)[O-])N1C(=O)CCC1=O</smiles>
$92 \%, 90 \%$ ee $90 \%, 97 \%$ ee $77 \%, 92 \%$ ee

Scheme 37.

Organocatalytic aminohalogenation of eneamines 


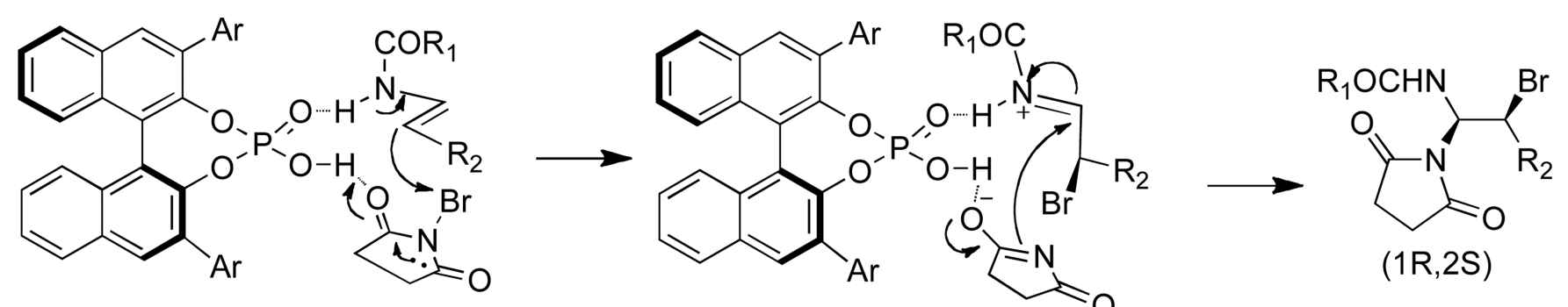
$\mathrm{Ar}=2,4,6-1 \mathrm{Pr}_{3} \mathrm{C}_{6} \mathrm{H}_{2}$

Scheme 38.

Proposed Mechanism 
<smiles>[R]C=CC=O</smiles><smiles>CC[C@H]([C@@H](F)CO)N(C)C(=O)OCc1ccccc1</smiles>

$73 \%, d r=95: 5$ $99 \%$ ee<smiles>C=CCC(C)N(C(=O)OCc1ccccc1)[C@@H](F)CO</smiles>

$61 \%, d r=93: 7$ $99 \%$ ee<smiles>CON(C(=O)OCc1ccccc1)[C@@H](COc1ccccc1)[C@H](F)CO</smiles>

$57 \%, d r=87: 13$ $99 \%$ ee<smiles>CON(C(=O)OCc1ccccc1)[C@@H](CC#N)[C@H](F)CO</smiles>
$41 \%, d r=91: 9$ $99 \%$ ee

Scheme 39.

Organocatalytic synthesis of chiral a-fluoro- $\beta$-amino alcohols 


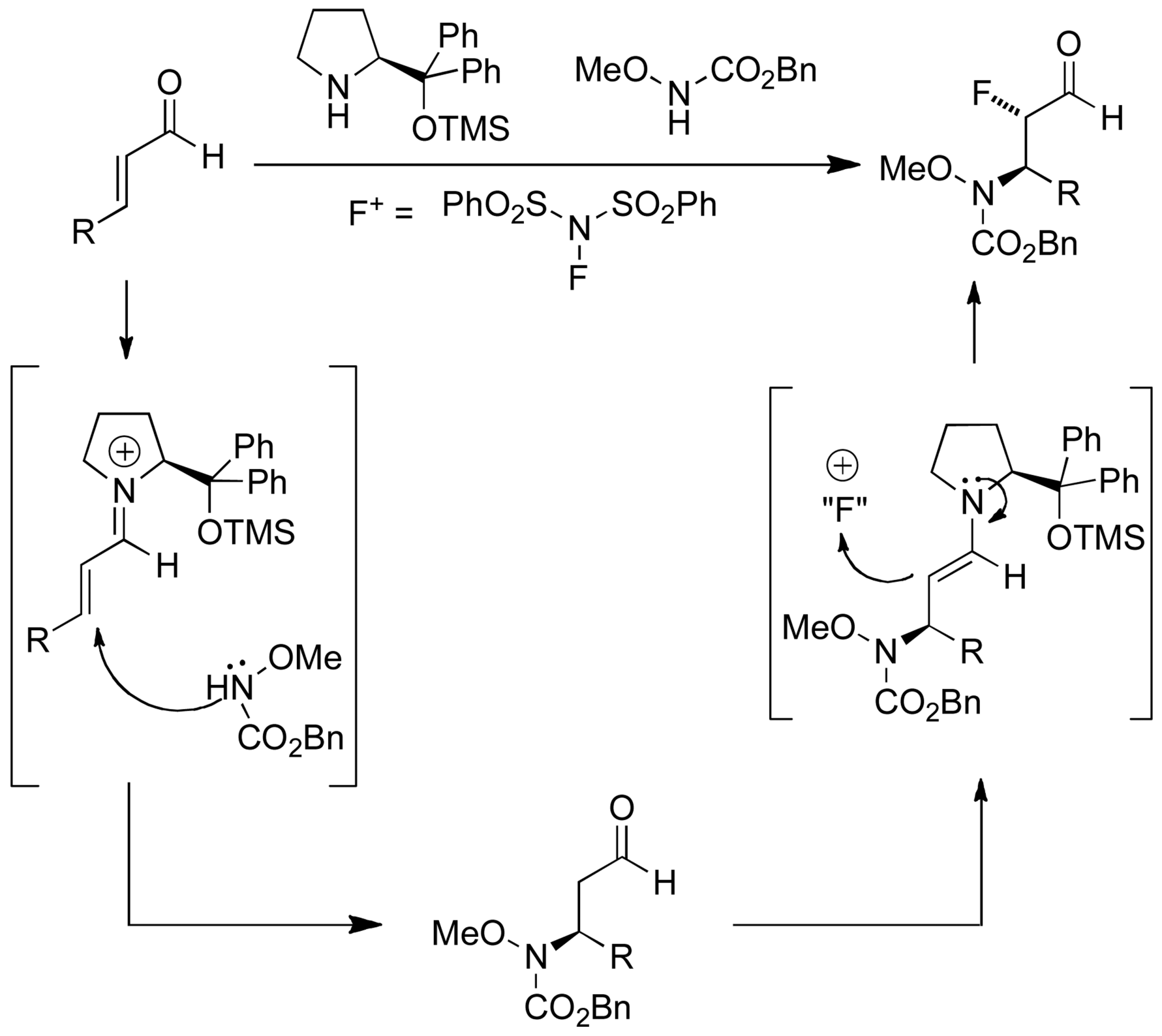

Scheme 40.

Proposed Organocatalytic Cascade Mechanism 


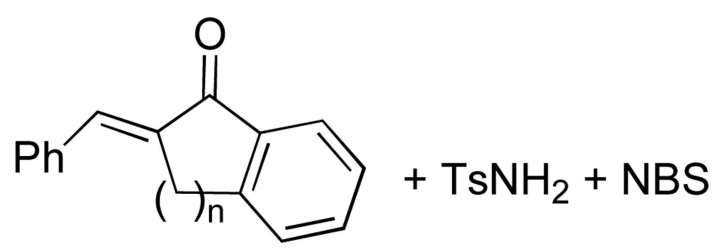

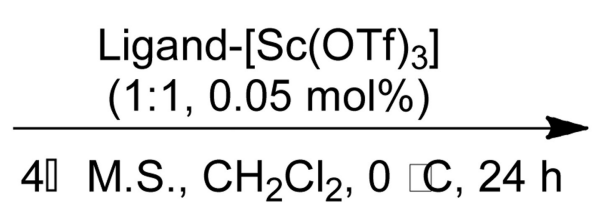

$$
\begin{aligned}
& n=1,68 \%, 97 \% \text { ee, }>99: 1 \text { d.r. } \\
& n=2,78 \%, 98 \% \text { ee, }>99: 1 \text { d.r. }
\end{aligned}
$$

Scheme 41.

Bromoamination of Rigid Enones 


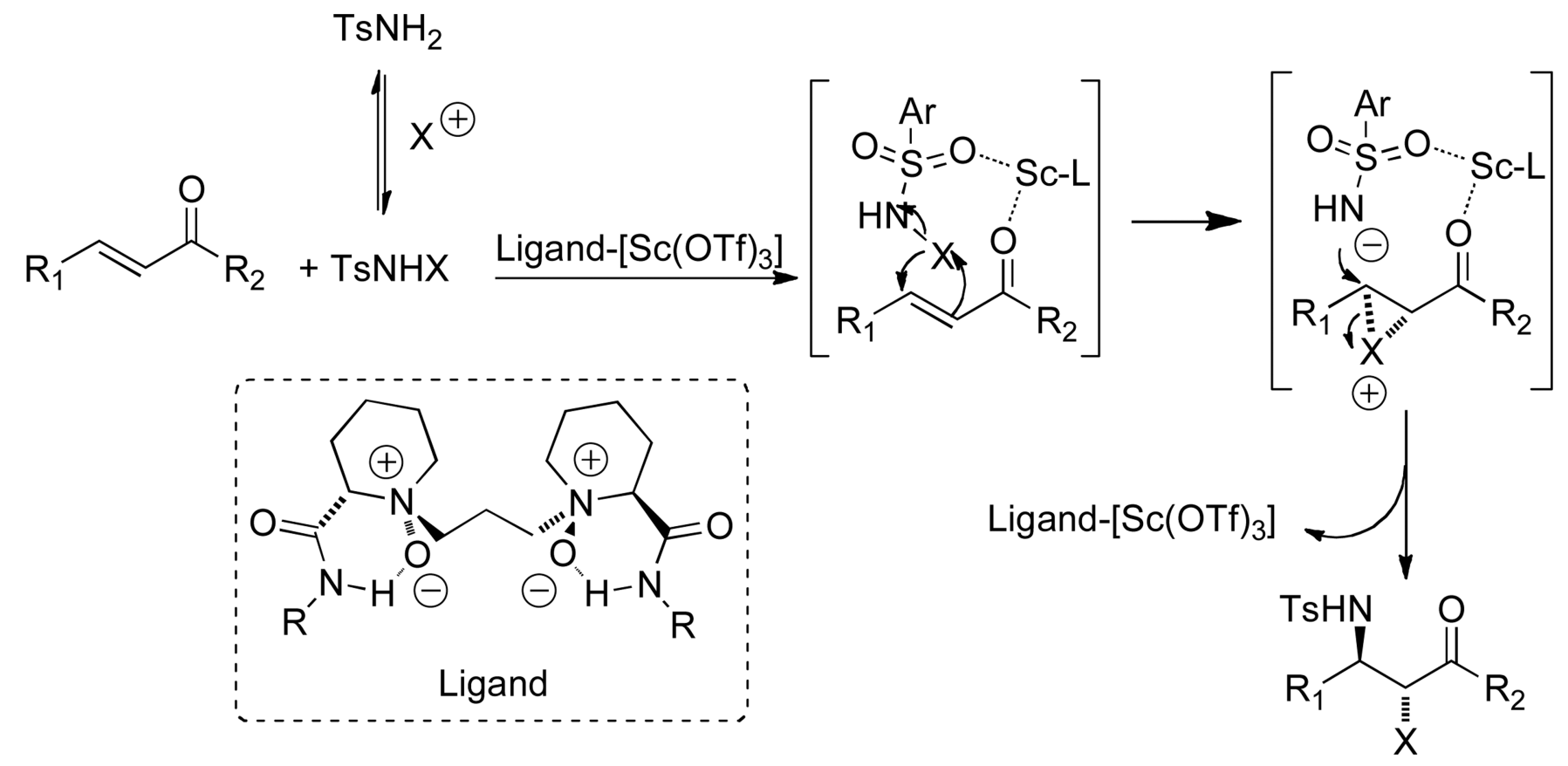

Scheme 42.

Proposed mechanism for the bromoamination of chalcones 


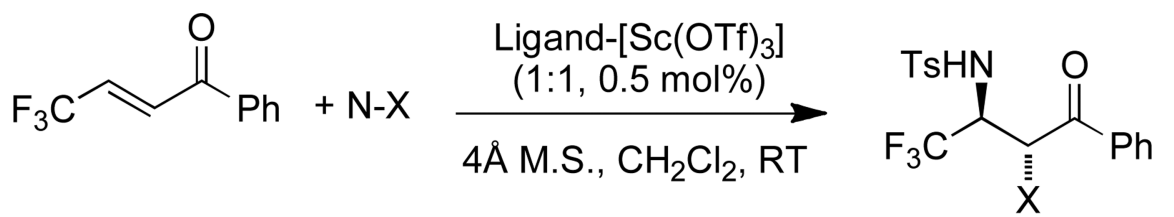

$\mathrm{N}-\mathrm{X}$ :

$\mathrm{TsNCl}_{2} / \mathrm{TsNH}_{2}$ (1:1, 0.6 equiv), $3 \mathrm{~h}, 96 \%, 93 \%$ ee, $\mathrm{dr}=96: 4$

$\mathrm{NBS} / \mathrm{TsNH}_{2}(1: 1,1.1$ equiv), $3 \mathrm{~h}, 95 \%, 95 \%$ ee, $\mathrm{dr}=98: 2$

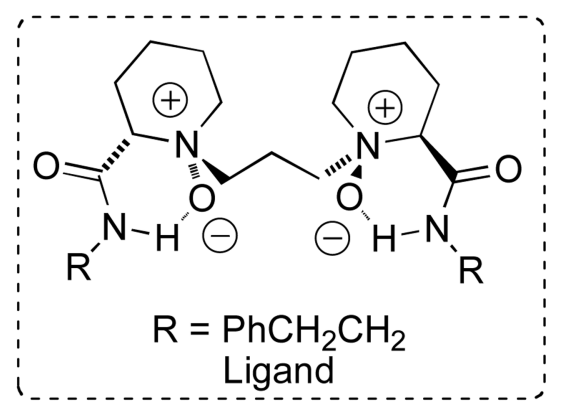

$\mathrm{NIS} / \mathrm{TsNH}_{2}$ (1:1, 1.1 equiv), $4 \mathrm{~h}, 93 \%, 98 \%$ ee, $\mathrm{dr}>95: 5$

Scheme 43.

Enantioselective Aminohalogenation of $\beta$-Trifluoromethyl Enones. 
Table 1

$\mathrm{Sc}(\mathrm{OTf})_{3}$-Catalyzed Enantioselective Bromoamination of Chalcones

\begin{tabular}{|c|c|c|c|c|}
\hline$R_{1}$ & 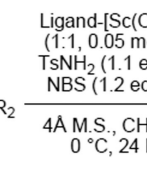 & IsHN & $\mathrm{R}$ & ${ }_{2} \mathrm{CH}_{2}$ \\
\hline entry & $\mathbf{R}^{1}$ & $\mathbf{R}^{2}$ & yield $(\%)$ & ee $(\%)$ \\
\hline 1 & $\mathrm{Ph}$ & $\mathrm{Ph}$ & 99 & 96 \\
\hline 2 & $\mathrm{Ph}$ & 2-naphthyl & 99 & 99 \\
\hline 3 & $\mathrm{Ph}^{a}$ & 2-furyl & 99 & 98 \\
\hline 4 & $\mathrm{PhCH}=\mathrm{CH}^{b}$ & $\mathrm{Ph}$ & 80 & 99 \\
\hline
\end{tabular}

$a_{\text {d.r. }}=98: 2$.

$b_{\text {d.r. }}=96: 4$ 


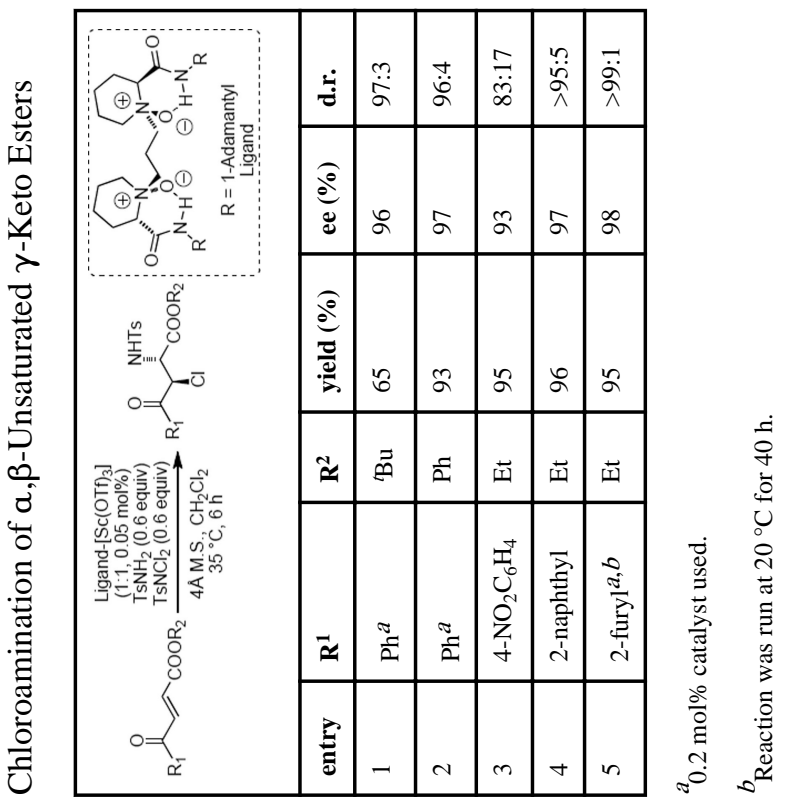




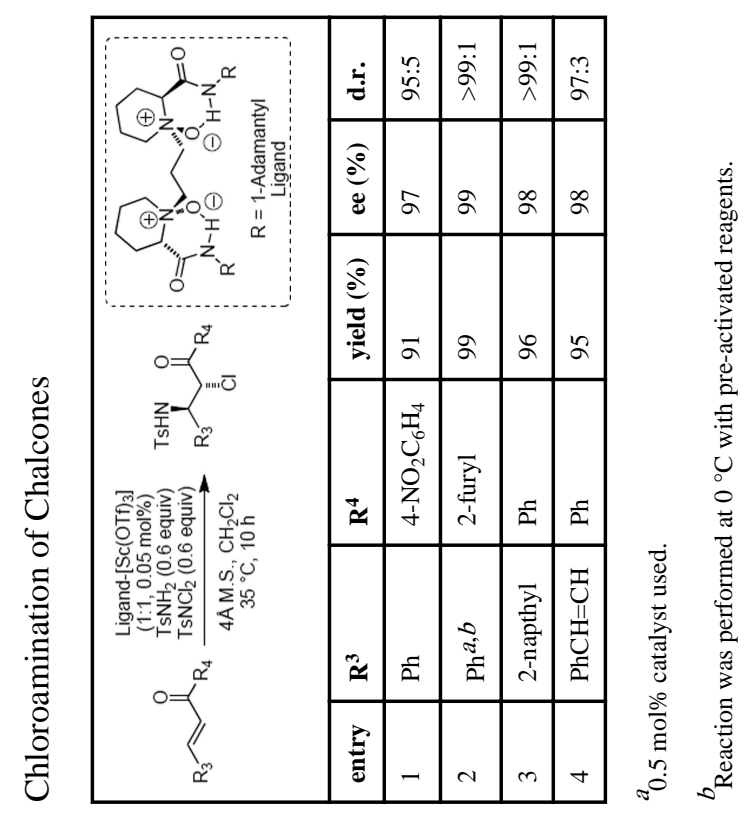

ACS Catal. Author manuscript; available in PMC 2014 June 07. 


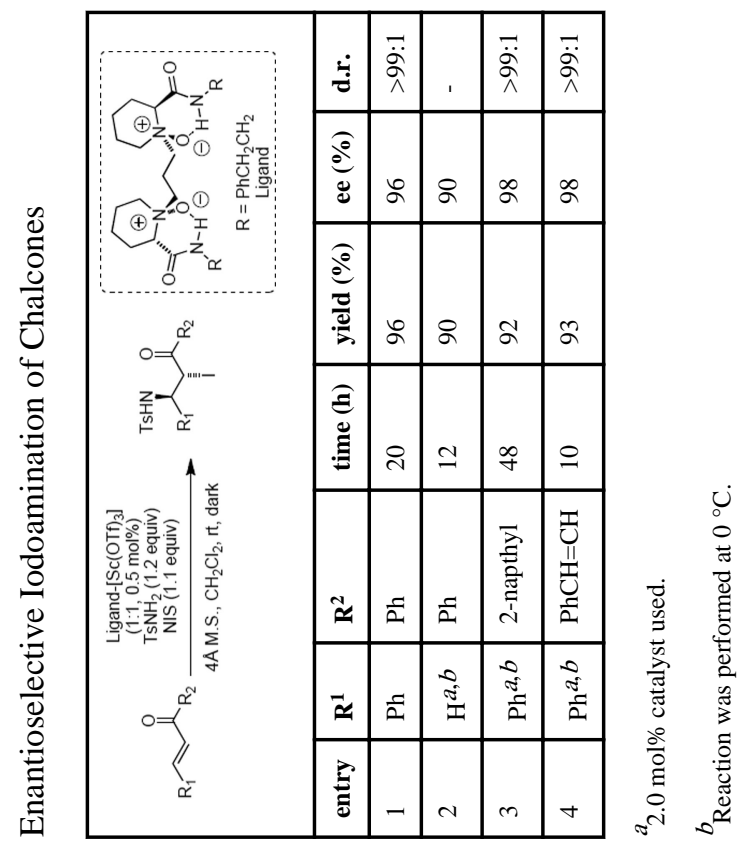

ACS Catal. Author manuscript; available in PMC 2014 June 07. 


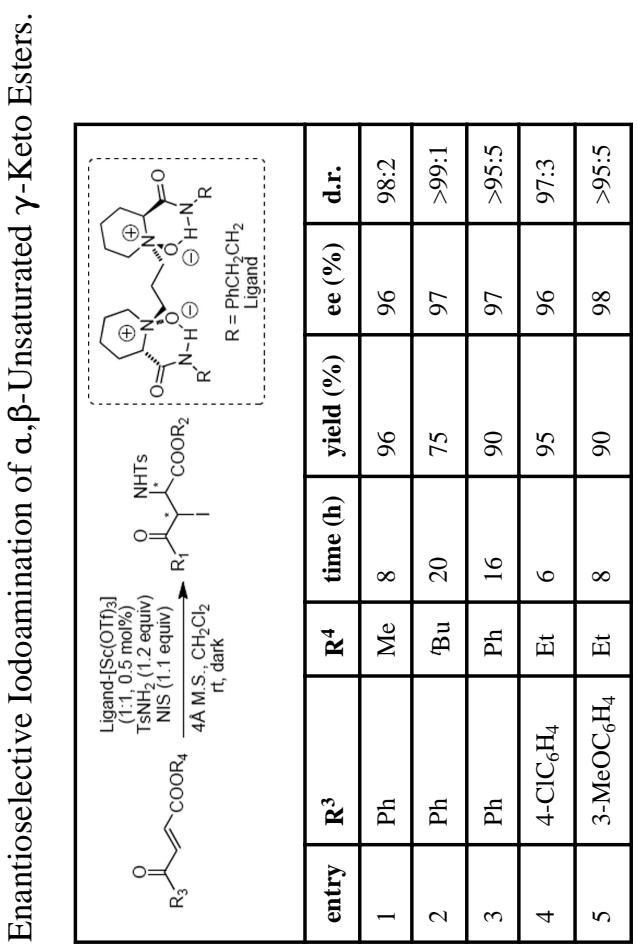

ACS Catal. Author manuscript; available in PMC 2014 June 07. 